\title{
Data report: radiolarian stratigraphy across the Eocene/Oligocene boundary in the equatorial Pacific, Sites 1218, U1333, and U1334'
}

Theodore C. Moore ${ }^{2}$ and Shin-ichi Kamikuri ${ }^{3}$

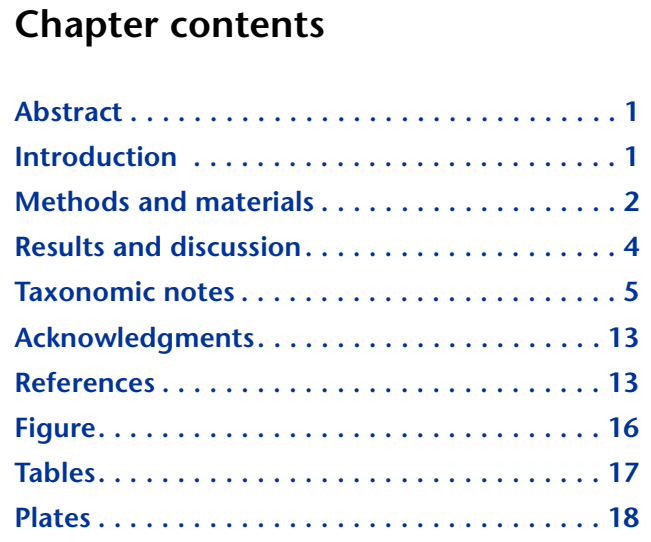

${ }^{1}$ Moore, T.C., and Kamikuri, S., 2012. Data report: radiolarian stratigraphy across the Eocene/ Oligocene boundary in the equatorial Pacific, Sites 1218, U1333, and U1334. In Pälike, H., Lyle, M., Nishi, H., Raffi, I., Gamage, K., Klaus, A., and the Expedition 320/321 Scientists, Proc. IODP, 320/ 321: Tokyo (Integrated Ocean Drilling Program Management International, Inc.). doi:10.2204/iodp.proc.320321.204.2012 ${ }^{2}$ Department of Earth and Environmental Sciences, University of Michigan, Ann Arbor Ml 48109-1005, USA. tedmoore@umich.edu

${ }^{3}$ Education Faculty, Ibaraki University, 2-1-1 Bunkyo, Mito, 310-8512, Japan.

\begin{abstract}
The interval spanning the uppermost Eocene to the lower Oligocene was a time of major climatic and oceanographic change, including major changes in sediment composition and faunal assemblages. Here we examine the radiolarian fauna during the Eocene-Oligocene transition (40-30 Ma) from three sites: Ocean Drilling Program Site 1218 and Integrated Ocean Drilling Program Sites U1333 and U1334, all of which appear to contain complete sections of the Eocene/Oligocene boundary and to have been located near the Pacific Equator during this time interval. Using previous work that interrelated the stratigraphic position of samples from all three sites, the abundance and first and last appearances of 76 stratigraphically important radiolarian species, species groups, and variant forms are documented in $>600$ samples. This quantitative analysis of species abundance has allowed us to accurately define 109 first and last appearance datums and to document the reworking of older microfossils into younger sections.
\end{abstract}

\section{Introduction}

The Eocene/Oligocene $(\mathrm{E} / \mathrm{O})$ boundary marks a major transition in climate, oceanography, and ocean circulation, and it takes place over a rather brief span of geologic time. For radiolarians it is associated with a comparatively large turnover of fauna (Funakawa et al., 2006). Unfortunately, the record of this transition in Pacific sediments is usually marked by poor carbonate preservation in the uppermost Eocene, hiatuses in the recovered sections, and immixed reworked older siliceous microfossils. In this report we present a detailed sampling of the only three sites from the equatorial Pacific that are believed to contain a complete stratigraphic record of the E/O boundary: Ocean Drilling Program (ODP) Site 1218 and Integrated Ocean Drilling Program (IODP) Sites U1333 and U1334 (Fig. F1, Table T1). In the data tables (Tables T2-T7) we give the abundance of 76 radiolarian species, species groups, and transitional forms in samples that span the time period of $\sim 40$ to $30 \mathrm{Ma}$. References to species descriptions and remarks concerning our observations and the nature of the transitional forms are given in a taxonomic list (see "Taxonomic notes"). Illustrations of most of the species and forms used are given in Plates P1-P10. 
Also given in the data tables are the counts of older, reworked radiolarian microfossils in each sample, as well as the ratio of diatom fragments to radiolarian shells (see "Methods and materials"). Based on our evaluation of this reworking, we give our best estimate of the first and last in situ occurrences of the species and forms whose range overlap or are included within the sampled interval at each site. We have used the corrected and adjusted sample depths at each site generated by Westerhold et al. (2012) and their correlation of these depths to similarly adjusted depths at Site 1218. In this way we hope to obtain the best possible constraints on individual biostratigraphic datum levels (Table T8).

\section{Methods and materials}

\section{Sites studied}

Only three sections have been recovered from the tropical Pacific that clearly show the "two-step" shift in lithology and geochemistry at the E/O boundary that we believe marks a truly complete stratigraphic section (Coxall et al., 2005). These three sites were also close to the paleoequatorial zone of high productivity during the E-O transition (Fig. F1; Table T1). Because of their completeness and because of their location within a very specific and important biogeographic and paleoceanographic zone, these three sites were selected for a detailed study of the E-O transition.

\section{Depths in sections}

The work of Westerhold et al. (2012) greatly facilitated this study by providing a revised depth scale for all holes at each of the three sites. This allowed samples from any given hole to be placed in relative stratigraphic order with respect to samples from all other holes at that site. This depth adjustment was based on a decimeter-scale correlation using multisensor logger data from all cores at each of the sites covered in their study (IODP Sites U1331-U1334 and ODP Sites 1218-1220). In a further refinement that is critical to sites used in this study, Sites U1333 and U1334 were correlated to Site 1218 using the same correlation techniques. This allowed us to place all samples used in this study on a common (Site 1218) depth scale, thus greatly enhancing our ability to refine the radiolarian stratigraphy at these three sites. Nomenclature for the depth scales used in Tables T2, T3, T4, T5, T6, and T7 follow the usage described by Westerhold et al. (2012).

\section{Samples}

Based on the correlation of multisensor logger data and paleomagnetic stratigraphy, $1 \mathrm{~cm}$ samples (onequarter core) were taken over the stratigraphic interval spanning from 40 to $30 \mathrm{Ma}$. Samples were taken from cores in individual holes that showed relatively complete and undisturbed recovery. There was some stratigraphic overlap of sampling when shifting from one hole to another in the sampling scheme. Sample spacing varied between $\sim 20$ and $50 \mathrm{~cm}$. A total of 641 samples were examined from the three sites used in this study (Tables T2, T3, T4, T5, T6, and T7). The average sample spacing in the sites is $\sim 35 \mathrm{~cm}$.

Samples were prepared following the procedures described in Sanfilippo et al. (1985). Sediment sample was placed in a beaker with $15 \% \mathrm{H}_{2} \mathrm{O}_{2}$ to remove organic material and a $\sim 20 \% \mathrm{HCl}$ solution to remove the calcareous fraction from the sediment. The sample was sieved and washed through a $63 \mu \mathrm{m}$ mesh sieve. If, upon visual inspection, the coarse residue was found to contain clumps of cemented clays and radiolarian fragments, the sample was treated for as long as 1 min in a concentrated solution of $\mathrm{NaOH}$ ( $\mathrm{pH}=\sim 11)$, immersed briefly $(\sim 15 \mathrm{~s})$ in an ultrasonic bath, and then re-sieved. This treatment usually disaggregated the cemented clumps and cleaned the radiolarian skeletons so that they could be more easily identified. Residues were randomly settled onto a slide (Moore, 1973), and then a $22 \mathrm{~mm} \times 40 \mathrm{~mm}$ coverslip was mounted on top using Norland optical adhesive \#61 as a mounting medium.

Slides were studied under a transmitted light microscope at $100 \times$ magnification (10x eyepiece, $10 \times$ objective). An estimate of the number of radiolarian specimens on each slide was made by counting the number of specimens in one vertical traverse of the slide (one column, $1.4 \mathrm{~mm}$ wide) and in one horizontal traverse (one row, $1.5 \mathrm{~mm}$ wide). These values were multiplied by the number of rows and number of columns scanned and averaged to estimate the total number of specimens examined on the slide. The number of columns scanned was adjusted to assure that between $\sim 5,000$ and 10,000 specimens were examined. In these slides a total of 76 species, species groups, and specific variant forms were counted (see "Taxonomic notes," below). In addition, all diatom valves and diatom girdles that appeared in the slides were counted. A qualitative estimate of preservation and abundance of radiolarians in the samples is given in the tables. 


\section{Species illustration}

Nearly all of the species, species groups, and variant forms listed in "Taxonomic notes" and in Tables T2, T3, T4, T5, T6, and T7 are illustrated in Plates P1, P2, P3, P4, P5, P6, P7, P8, P9, and P10. Photographs were taken with a ProgRes C3 digital microscope camera. A total of 10 to 30 individual photographs (each at a slightly different focal depth) were taken of each specimen illustrated. These shots were then stacked using Helicon Focus software in order to achieve an in-focus image of the entire three-dimensional form. This software was also used to select out-of-focus images of surrounding radiolarian shells and fragments.

\section{Determining biostratigraphic datum levels}

Although their sections are judged to be complete, the sediments of all three sites studied appear to contain varying amounts of reworked older microfossils. Many radiolarian species become extinct near the close of the Eocene, but radiolarian stratigraphy of the uppermost Eocene has always been plagued by the fact that the reworking of older microfossils makes the exact level of extinction of these species suspect. Nigrini et al. (2006) acknowledged this problem and indicated both the "last occurrence" and the "last continuous occurrence" of several upper Eocene species whose last occurrence in the samples may have been affected by reworking and immixing.

Of the sites studied here, Site U1334 appears, on average, to have the fewest immixed older microfossils in the samples studied. To some extent this may result from its being drilled on the youngest crust of the three sites ( $\sim 38 \mathrm{Ma})$. Here we take the last continuous occurrence of a species to be its last appearance datum (LAD), relying primarily on the last continuous occurrence of the species at Site U1334. Because we can accurately relate this depth to equivalent depths at all three sites through the Westerhold et al. (2012) correlations to Site 1218, we can evaluate the LADs, as well as first appearance datums (FADs), at all sites studied and often more tightly constrain the level of all datums (Table T8). The relatively dense sampling in the sites studied often aids us in determining the continuous versus the discontinuous presence of a species.

However, there are two exceptions to this general guideline. First, if a species is very rare throughout its range, there may be samples within its range in which it is not found. Because such very rare species are statistically less likely to be reworked into younger sediments, the upper limit of its stratigraphic range can usually be determined unambigu- ously. There are only a few species studied that are both so rare and so intermittent in occurrence that their stratigraphic usefulness is doubtful (e.g., Pteropilium sp. aff. Pterocanium contiguum).

The second exception is where the last continuous occurrence at one site is above that at the other sites. Usually in such cases data from Site U1334 defines the lowest last continuous occurrence and one of the other (or in rare cases, both) sites has continuous occurrences of the species above that level. For the purposes of defining the error bars of LADs with such a discrepancy, the last continuous occurrence is accepted for each site; thus, the error bars are broader for that datum. However, for the purposes of defining the amount of reworked material in each sample, the lowest last continuous occurrence found at the three sites is taken to be the correct level of the LAD of the species and samples from other sites containing specimens of this species above the equivalent depth of the lowest LAD are assumed to have been reworked.

\section{Species definition}

We generally adhere to the taxonomy found in Nigrini et al. (2006), and we do not try to define new species that appear in the samples studied. However, we are interested in tracing the details of how the Eocene fauna is decimated by major climatic and paleoceanographic changes near the E/O boundary and how the radiolarian fauna develops and expands in the lower Oligocene. In so doing the new species described in Nigrini et al. (2006) have been very helpful. In addition we have identified 12 transitional forms that help link the development of new species in both the upper Eocene and lower Oligocene (Tables T2, T3, T4, T5, T6, and T7):

Dorcadospyris cf. Dorcadospyris ateuchus

Dorcadospyris aff. Dorcadospyris pseudopapilio

Dorcadospyris cf. Dordacospyris ombros

Dorcadospyris aff. Dorcadospyris spinosa

Dorcadospyris cf. Dorcadospyris spinosa

Lithocyclia cf. Lithocyclia crux, var. A

Lithocyclia cf. Lithocyclia crux, var. B

Lithocyclia cf. Lithocyclia crux, var. C

Theocyrtis aff. Theocrytis careotuberosa

Thyrsocyrtis (Pentalacorys) aff. Thyrsocyrits (Pentalacorys) lochites

Thyrsocyrtis (Thyrsocyrtis) cf. Thyrsocyrtis (Thyrsocyrtis) norrisi

Thyrsocyrtis (Thyrsocyrtis) aff. Thyrsocyrtis (Thyrsocurtis) pinguisicoides

Some of these forms appear only briefly in the section (over 2-4 m of Site 1218 equivalent depth) and 
would likely have been missed in studies with coarser sample spacing.

\section{Results and discussion}

In this study we restricted our tabulation of species to those that have been shown to be stratigraphically useful and whose evolution has to some degree been traced in the many studies of W.R. Riedel, A. Sanfilippo, C. Nigrini, J. Westberg, D. Johnson, and others. However, this species list by no means encompasses the great diversity of radiolarian species that exist over the interval of time studied. The stratigraphically important species we used do emphasize the radiolarian faunal turnover that took place in this interval of time. A study of faunal turnover based on the more abundant radiolarian species in a broader study of the E-O interval (Funakawa et al., 2006) shows the same general pattern of faunal change seen in the data presented here.

Given that these sites are sampled over approximately the same stratigraphic interval and can be correlated in detail using the work of Westerhold et al. (2012), the composite sample resolution is greater than the $35 \mathrm{~cm}$ average sample spacing. However, given the complexity engendered by the reworking of older microfossils and the possible diachrony of some datum levels, the average error bars on the biostratigraphic datums are a little over $\pm 25 \mathrm{~cm}$ (Table T8). It is apparent from Tables T2, T3, T4, T5, T6, and $\mathrm{T} 7$ that the reworking of older microfossils into the younger section is primarily a problem in the upper Eocene. In the Oligocene, reworked material is still identified but the amount of this material drops markedly.

There are 47 FADs and 62 LADs identified in Table T8. Each datum is given an estimated error based on the procedure described in "Determining biostratigraphic datum levels." Also given in Table T8 is an estimate of the reliability of each datum based on how many sites it was identified in, whether or not the sites agreed on the datum position, and how abundant the species was:

$1=$ overlapping depth range at all three sites.

2 = overlapping depth range at two sites, not observed in third site.

$3=$ nonoverlapping range at one site (possible diachrony or mixing). Best estimate based on two sites.

$4=$ nonoverlapping depth range at all sites, abundance $>0.02 \%$. Best estimate based on depth range of all samples.
5 = nonoverlapping depth range at all sites, abundance $<0.02 \%$ Best estimate based on depth range of all samples.

As might be expected, the average reliability of FADs is better $(<2.0)$ than that of LADs $(>2.0)$ (Table T8).

We selected the three sites to study based on their completeness. In addition, these three sites lay close to the paleoequator during the 30-40 Ma time interval and might be considered to lie within the same biogeographic province. Thus, the chance of diachrony in the first or last appearances of species is minimized. However, study of late Neogene biostratigraphic datums in the eastern tropical Pacific suggested that a small degree of diachrony might well exist in relatively small regions that have high oceanographic and ecologic gradients (Moore et al., 1993).

The estimate of how close these sites actually were to the Equator during the interval studied depends on the plate rotation and reconstruction model used (Table T1). ODP Leg 199 (Lyle, Wilson, Janecek, et al., 2002) used Engebretson et al. (1985) and Gripp and Gordon (1990). IODP Expedition 320/321 (see the "Expedition 320/321 summary" chapter [Pälike et al., 2010]) used Koppers et al. (2001), Engebretson et al. (1985), and paleopole data from Sager and Pringle (1988). Moore et al. (2004) used the Leg 199 plate rotation model and showed, through the mapping of sediment accumulation rates in the equatorial Pacific high-productivity zone, that the apparent axis of high accumulation rates appeared to be tilted toward the southwest. Given our understanding of equatorial divergence and its affect on productivity, the axis of high sediment accumulation rates should lie exactly on the Equator. A small correction to plate rotation models could be made to produce a map of accumulation rates consistent with our understanding of the forces controlling equatorial divergence (fig. 6 in Moore et al., 2008). This correction may be necessitated by the fact that the hotspot reference point used for plate rotation is itself slowly moving (Parés and Moore, 2005).

The difference in the latitudinal positions of the studied sites and the model used during Leg 199 is not greatly different from that used during Expedition $320 / 321\left(\sim 0.2^{\circ}-0.4^{\circ}\right.$ of latitude). However, the difference between the positions defined by these models and those having the corrections indicated by Parés and Moore (2005) and Moore et al. (2008) amount to $\sim 1^{\circ}$ of latitude (Table T1). If the influence of the equatorial divergence only extends $\pm 2^{\circ}$ of latitude from the Equator, a difference of $1^{\circ}$ latitude in estimated site position could be important. It would 
place Site U1333 outside the zone of equatorial divergence through much of the early Oligocene and perhaps within the influence of the North Equatorial Countercurrent divergence (Moore et al., 2004).

An abundance of diatom tests flooded the $>63 \mu \mathrm{m}$ siliceous fraction in many of the samples from sites sampling the lower Oligocene (Tables T2, T3, T4, T5, T6, and T7). This is a fairly unusual occurrence, not seen in older sections from the tropical Pacific and rarely seen in younger intervals. Diatoms are considered one of the main primary producers in the open ocean. It may be that this relative abundance of large diatoms reflects changes in the structure of the upper ocean in the tropical Pacific resulting in changes in the productivity of these waters.

\section{Taxonomic notes}

\section{Anthocyrtoma spp.}

Plate P1, fig. 1

Anthocyrtoma spp. Nigrini et al., 2006, p. 25, pl. P3, figs. 15, 16

\section{Artophormis barbadensis (Ehrenberg)} Plate P1, fig. 2

Calocyclas barbadensis Ehrenberg, 1873, p. 217; 1875, pl. 18 , fig. 8

Artophormis barbadensis (Ehrenberg), Haeckel, 1887, p. 1459; Riedel and Sanfilippo, 1970, p. 532, pl. 13, fig. 5; Nigrini et al., 2006, p. 25, pl. P3, figs. 17-19

\section{Artophormis dominasinensis (Ehrenberg)}

Plate P1, fig. 3

Podocyrtis dominasinensis Ehrenberg, 1873, p. 250; 1875, pl. 14, fig. 4

Artophormis dominasinensis (Ehrenberg), Riedel and Sanfilippo, 1970, p. 532; 1971, p. 1592, pl. 6, fig. 6; Nigrini et al., 2006, p. 25, pl. P4, fig. 1

\section{Artophormis gracilis Riedel}

Plate P1, fig. 4

Artophormis gracilis Riedel, 1959, p. 300, pl. 2, figs. 12, 13; Riedel and Sanfilippo, 1970, p. 532, pl. 13, fig. 6; 1971, pl. 3B, figs. 5-7; pl. 6, fig. 7; Sanfilippo and Nigrini, 1995 , p. 272 , pl. I, figs. $1-5$

?Artophormis fluminafauces O'Connor, 1999, p. 20, pl. 3, figs. 12-16b; pl. 6, figs. 24a-27

Artophormis gracilis Riedel, Nigrini et al., 2006, p. 26, pl. P3, figs. 20-22

\section{Calocyclas bandyca (Mato and Theyer) \\ Plate P1, figs. 5, 6}

Lychnocanoma bandyca Mato and Theyer, 1980, p. 225, pl. 1, figs. $1-6$
Calocyclas bandyca (Mato and Theyer), Sanfilippo and Riedel in Saunders et al., 1984, p. 411, pl. 5, figs. 1, 5, 6

Remarks: Early in its range Calocyclas bandyca may have more than three primary feet (compare Plate P1, figs. 5 and 6; see also pl. 5, fig 5.6 in Saunders et al., 1984).

\section{Calocyclas hispida (Ehrenberg)}

Plate P1, figs. 7, 8

Anthocyrtis hispida Ehrenberg, 1873, p. 216; 1875, pl. 8, fig. 2

Calocyclas hispida (Ehrenberg), Foreman, 1973, p. 434, pl. 1, figs. $12-15$; pl. 9 , fig. 18

\section{Calocyclas turris Ehrenberg Plate P1, figs. 9, 10}

Calocyclas turris Ehrenberg, 1873, p. 218; 1875, pl. 18, fig. 7; Foreman, 1973, p. 434

\section{Calocycletta (Calocycletta) anekathen Sanfilippo and Nigrini \\ Plate P1, fig. 11}

Theocyrtis tuberosa Riedel, Moore, 1971, p. 743, pl. 5, fig. 5 only (part)

Calocycletta virginis Haeckel sensu stricto, in Petrushevskaya and Kozlova, 1972, p. 544, pl. 35, figs. 8-10

Calocycletta (Calocycletta) anekathen Sanfilippo and Nigrini, in Nigrini et al., 2006, pp. 27-28, pl. P5, figs. 7-9

\section{Calocycloma ampulla (Ehrenberg)}

Plate P1, fig. 12

Eucyrtidium ampulla Ehrenberg, 1854, pl. 36, fig. 15a-15c; 1873 , p. 22

Calocycloma ampulla (Ehrenberg), Foreman, 1973, p. 434, pl. 1, figs. 1-5; pl. 9, fig. 20

\section{Centrobotrys gravida Moore Plate P1, fig. 13}

Centrobotrys gravida Moore, 1971, p. 744, pl. 5, fig. 8

Remarks: In the material studied the first appearance of this species may be diachronous, appearing first at Site U1333, then at Site 1218, and lastly at Site U1334.

\section{Centrobotrys petrushevskayae Sanfilippo and Riedel Plate P1, fig. 14}

Centrobotrys (?) sp. A Riedel and Sanfilippo, 1971, p. 1602, pl. 3 F, figs. 15,16

Centrobotrys petrushevskayae Sanfilippo and Riedel, 1973, p. 532, pl. 36, figs. 12, 13; Nigrini et al., 2006, p. 30, pl. P6, figs. 22,23

\section{Cryptocarpium azyx (Sanfilippo and Riedel) Plate P2, fig. 1}

Carpocanistrum azyx Sanfilippo and Riedel, 1973, p. 530, pl. 35, fig. 9 
Cryptocarpium azyx (Sanfilippo and Riedel), Sanfilippo and Riedel, 1992, p. 6, pl. 2, fig. 21

Remarks: A variety of Cryptocarpium ornatum with fine pores and an inflated thorax overlaps the range of C. azyx and can be confused with it. C. azyx has a more constricted termination and does not show clear evidence of an abdomen (compare with Plate P2, fig. 2).

\section{Cryptocarpium ornatum (Ehrenberg) \\ Plate P2, figs. 2-4}

Cryptoprora ornata Ehrenberg, 1873, p. 222; 1875, pl. 5, fig. 8; Sanfilippo et al., 1985, p. 693, fig. 27.2a, 27.2b

Cryptocarpium ornatum (Ehrenberg), Sanfilippo and Riedel, 1992, pp. 6, 36, pl. 2, figs. 18-20

Remarks: The morphology of this species varies significantly in size and outline (compare Plate P2, figs. 2-4). Further studies may find it useful to separate the more inflated form (fig. 2) from those forms having a more cylindrical outline. See also Sanfilippo et al. (1985) for a discussion of variation in this species.

\section{Dictyoprora armadillo (Ehrenberg) group Plate P2, fig. 5}

Eucyrtidium armadillo Ehrenberg, 1873, p. 225; 1875, p. 70, pl. 9, fig. 10

Theocampe armadillo (Ehrenberg) group, Riedel and Sanfilippo, 1971, p. 1601, pl. 3E, figs. 3-5 (partim.)

Dictyoprora armadillo (Ehrenberg), Nigrini, 1977, p. 250, pl. 4, fig. 4; Nigrini et al., 2006, p. 31, pl. P6, fig. 9

Remarks: As used by Nigrini et al. (2006) and herein, this group may encompass more than one species; however, the last appearance of this form in the uppermost Eocene is consistent in all three sites studied. As in Nigrini et al. (2006), we confine the species to those individuals with 10-15 transverse rows of circular pores.

\section{Dictyoprora mongolfieri (Ehrenberg) \\ Plate P2, fig. 6}

Eucyrtidium mongolfieri Ehrenberg, 1854, pl. 36, fig. 18B lower; 1873, p. 230

Dictyoprora mongolfieri (Ehrenberg), Nigrini, 1977, p. 250, pl. 4 , fig. 7

\section{Dorcadospyris anastasis Sanfilippo Plate P2, figs. 7, 8}

Dorcadospyris anastasis Sanfilippo, in Nigrini et al., 2006, pp. 33-34, pl. P1, figs. 11, 12

\section{Dorcadospyris ateuchus (Ehrenberg)}

Ceratospyris ateuchus Ehrenberg, 1873, pl. 218; 1875, pl. 21, fig. 4D

Cantharospyris ateuchus (Ehrenberg), Haeckel, 1887, p. 1051; Riedel, 1959, p. 294, pl. 22, figs. 3, 4

Dorcadospyris ateuchus (Ehrenberg), Riedel and Sanfilippo, 1970, p. 523, pl. 15, fig. 4; Sanfilippo and Nigrini, 1995, p. 275 , pl. III, figs. 2-4; Nigrini et al., 2006, p. 34, pl. P1, figs. $13-15$

Remarks: This species was not found in the material studied. See Nigrini et al., 2006, p. 34, pl. P1, figs. 13-15, for illustrations in order to compare it to $D$. cf $D$. ateuchus (see below).

\section{Dorcadospyris cf. D. ateuchus (Ehrenberg) Plate P2, figs. 10, 11}

Remarks: This form first appears in the earliest Oligocene, stratigraphically separated from Dorcadospyris ateuchus. Similar to $D$. ateuchus it has two relatively straight, downwardly divergent primary feet and two to four lamellar secondary feet; however, it may also have another somewhat longer secondary foot that is cylindrical in cross section and extends from the base of the shell at the junction with the sagital ring. It is smaller in cross section and shorter in length than the cylindrical primary feet (Plate P2, fig. 11). This form appears to be intermediate between the form of Tristylospyris triceros having lamellar secondary feet and Dorcadospyris aff. D. pseudopapilio (see remarks below under Dorcadospyris aff. D. pseudopapilio). The upper part of its short range overlaps with the lower part of the range of Dorcadospyris aff. D. pseudopapilio.

\section{Dorcadospyris circulus (Haeckel)}

Gamospyris circulus Haeckel, 1887, p. 1042, pl. 83, fig. 19 Dorcadospyris circulus (Haeckel), Moore, 1971, p. 739, pl. 8, figs. 3-5

Dorcadospyris circulus (Haeckel), Nigrini et al., 2006, p. 34, pl. P1, fig. 16

Remarks: This species first appears slightly above the samples studied here. See Nigrini et al., 2006, p. 34, pl. P1, figs. 13-15, for illustrations. It may evolve from $D$. $m a-$ hurangi (see below).

\section{Dorcadospyris copelata Sanfilippo Plate P2, figs. 9, 12}

Dorcadospyris copelata Sanfilippo, in Nigrini et al., 2006, p. 34, P1, figs. 19, 20; pl. P2, figs. 1, 2

Remarks: Tristylospyris triceros, as used here, does include forms with tabular feet; however, they are less broad and more delicate than those of Dorcadospyris copelata. The range Tristylospyris triceros with lamellar secondary feet extends into the lower Oligocene, above the last occurrence of Dorcadospyris copelata.

\section{Dorcadospyris mahurangi (?) O'Connor Plate P3, figs. 1, 2}

Dorcadospyris mahurangi O'Connor, 1994, p. 338, pl. 1, figs $1-4$, pl. 3, figs. 1-3

Remarks: This form appears to be intermediate between Tristylospris triceros and Dorcadospyris circulus. It first appears just below the first occurrence of $D$. circulus and has two primary feet that curve in a semicircular arc and a third, relatively straight primary foot that extends 
obliquely downward, very similar to D. mahurangi, as described by O'Connor (1994). In early forms the two arched primary feet do not cross. In later forms they may cross and even join, but do not usually form a smooth circle as in D. circulus.

\section{Dorcadospyris ombros Sanfilippo Plate P3, figs. 3, 4}

Dorcadospyris ombros Sanfilippo, in Nigrini et al., 2006, p. 36 , pl. P2, figs. 5,6

\section{Dorcadospyris cf. D. ombros Sanfilippo Plate P3, figs. 6, 7}

Remarks: Similar to Dorcadospyris ombros in its general morphology, this form usually has five long, cylindrical feet, similar in length and thickness, that diverge at an angle of $<180^{\circ}$ and then curve to extend straight downward. The distal part of the feet taper and recurve gently. However, it is stratigraphically separated from D. ombros, and the terminations of the primary feet do not show the sharply curved upward aspect seen in the later forms of $D$. ombros. This form occurs before the last appearance of and is likely descended from $D$. quadripes in the mid-Oligocene.

\section{Dorcadospyris pseudopapilio Moore Plate P3, fig. 5}

Dorcadospyris pseudopapilio Moore, 1971, p. 738, pl. 6, figs. 7, 8; Nigrini et al., 2006, p. 37, pl. P2, figs. 16, 17

\section{Dorcadospyris aff. D. pseudopapilio Moore} Plate P3, figs. 8, 9

Remarks: this form resembles Dorcadospyris pseudopapilio in its relatively strong apical horn and its latticed secondary feet. It differs in that the two primary feet diverge at an angle distinctly less than $\sim 180^{\circ}$. There may be more than two latticed secondary feet, and in some specimens only a fringe of lattice work is preserved. It is the likely ancestor of D. pseudopapilio in that it precedes and overlaps the first appearance of that species. It differs from $D$. cf. $D$. ateuchus (see above) in having curved feet and a relatively prominent apical horn.

\section{Dorcadospyris quadripes Moore (emend. herein) Plate P4, figs. 1-3}

Dorcadospyris quadripes Moore, 1971, p. 738, pl. 7, figs. 3-5; Nigrini et al., 2006, pp. 37-38, pl. P2, figs. 14, 15

Remarks: As noted in Nigrini et al. (2006), at least some of the $D$. quadripes specimens in their Leg 199 material have a broadly arching $\left(>180^{\circ}\right)$ pair of primary feet that arise from the apical part of the cortical shell rather than from the base of the shell (as described by Moore, 1971, p. 738). In this study we emend the description of $D$. quadripes to include specimens that have these broadly arching primary feet extending from the apical part of the cortical shell (Plate P4, figs. 2, 3). These forms tend to occur later in the range of this species and can co-occur with forms that have primary feet arising from the base of the shell.

As noted in Nigrini et al. (2006), forms of D. quadripes with broadly arching primary feet arising from the cortical shell are similar to $D$. riedeli.

"However, there are several features that distinguish the two species. In $D$. riedeli the broadly arching pair of feet always arise from the apical part of the cortical shell and the secondary pair of feet extend from the basal ring at nearly $180^{\circ}$ and curve to form a circle or ellipse (sometimes crossing, but usually not joined). D. riedeli never has more than four primary feet, whereas $D$. quadripes may have six to eight. The primary feet of $D$. quadripes that are not broadly arching extend from the basal ring at an angle distinctly $<180^{\circ}$. They tend to diverge distally and recurve only slightly" (Plate P4, fig. 3). "The stratigraphic ranges of the two species are different, with $D$. quadripes occurring in Zone RP20 and D. riedeli occurring most abundantly, but not exclusively, in the upper part of Zone RP22."

\section{Dorcadospyris spinosa Moore Plate P4, figs. 8, 9}

Dorcadospyris spinosa Moore, 1971, p. 739, pl. 6, figs. 1, 2; Nigrini et al., 2006, p. 39, pl. P3, figs. 13, 14

Remarks: The degree to which the primary feet show spines is highly variable in the material studied, particularly in the earlier part of the range of this species. Often only the distal part of the primary feet (basal part of the joined feet) show irregularly spaced spines (see Plate P4, fig. 8).

\section{Dorcadospyris aff. D. spinosa Moore Plate P4, figs. 6, 7}

Remarks: This form resembles Dorcadospyris spinosa in nearly all respects except for the absence of spines on its primary feet. Its upper range overlaps the basal part of the range of $D$. spinosa and it is thought to be the ancestor of D. spinosa.

\section{Dorcadospyris cf. D. spinosa Moore}

Plate P4, figs. 4, 5

Remarks: This very rare form is only found in the uppermost Eocene and resembles $D$. spinosa only in that the multiple primary feet have similar spines. There are usually only four primary feet extending from the base of the shell in a broad semicircular arch with two or more very thin secondary feet that are rarely preserved. The primary feet do not join but usually terminate in an upturned spine, very similar to the termination of the primary feet seen in later specimens of $D$. ombros. The range of this form lies within the range of $D$. ombros and is believed to derive from that species. 
Eucyrtidium plesiodiaphanes Sanfilippo

Plate P5, figs. 2, 3

Artophormis cf. A. gracilis in Moore, 1971, p. 742, pl. 5, fig. 12

Eucyrtidium plesiodiaphanes Sanfilippo, in Sanfilippo and Nigrini, 1995, p. 278, pl. 1, figs. 12-14, 16; Nigrini et al., 2006, p. 40, pl. P4, figs. 11, 12

\section{Eusyringium fistuligerum (Ehrenberg) Plate P5, fig. 1}

Eucyrtidium fistuligerum Ehrenberg, 1873, p. 229; 1875, pl. 9 , fig. 3

Eusyringium fistuligerum (Ehrenberg), Riedel and Sanfilippo, 1970 , p. 527, pl. 8, figs. 8, 9; Sanfilippo and Blome, 2001, p. 212, figs. 9a-9d; Nigrini et al., 2006, p. 40, pl. P4, fig. 13

\section{Lithochytris vespertilio Ehrenberg} Plate P5, fig. 4

Lithochytris vespertilio Ehrenberg, 1873, p. 239; 1875, pl. 4, fig. 10; Riedel and Sanfilippo, 1971, p. 528, pl. 9, figs. 8, 9

Remarks: This study did not sample material within the stratigraphic range of this species; however, specimens were found in our samples along with other reworked, older microfossils.

\section{Lithocyclia angusta (Riedel) Plate P5, figs. 5, 7, 8}

Trigonactura? angusta Riedel, 1959, p. 292, pl. 1, fig. 6 Lithocyclia angustum (Riedel), Riedel and Sanfilippo, 1970, p. 522 , pl. 13 , figs. 1,2

Lithocyclia angusta (Riedel), Sanfilippo and Riedel, 1973, p. 523; Sanfilippo et al., 1985, p. 653, fig. 7.3a-7.3c

\section{Lithocyclia aristotelis (Ehrenberg) group Plate P5, figs. 6, 9}

Astromma aristotelis Ehrenberg, 1847, p. 55, fig. 10

Lithocyclia aristotelis (Ehrenberg) group, Riedel and Sanfilippo, 1970 , p. 522, pl. 3, figs. 1, 2

\section{Lithocyclia crux Moore} Plate P5, fig. 10

Lithocyclia crux Moore, 1971, p. 737, pl. 6, fig. 4

\section{Lithocyclia cf. L. crux Moore, var A Plate P5, figs. 11, 14}

Remarks: The appearance of this species slightly precedes that of Lithocyclia cf. L. crux, var. B and has cortical and medullary shells very similar to that variant. The cortical shell is somewhat smaller than that of $L$. crux. The outer medullary shell is irregular in shape and, unlike $L$. crux, more than half as broad as the cortical shell. A second, inner medullary shell is less than half as broad as the outer medullary shell. Bars connecting the inner to the outer medullary shell attach at marked indentations in the outer shell. A spongy patagium surrounds the cortical shell. In well-preserved specimens, four narrow, symmetrically arranged spongy arms extend beyond the patagium and appear to support a nearly square outline of the patagium (fig. 14). When these arms are not preserved, the patagium often retains remnants of this outline (Plate P5, fig. $11)$.

\section{Lithocyclia cf. L. crux Moore, var. B Plate P5, figs. 12, 13}

Lithocyclia? sp., Nigrini et al., 2006, pl. P1, fig. 8

Remarks: As in Lithocyclia cf. L. crux Moore, var., A, the cortical shell is somewhat smaller than that of $L$. crux. The outer medullary shell is irregular in shape and more than half as broad as the cortical shell. A second, inner medullary shell is less than half as broad as the outer medullary shell. Bars connecting the inner to the outer medullary shell attach at marked indentations in the outer shell. Four broad spongy arms are arranged symmetrically and radiate out from the cortical shell. In older specimens these arms are nearly as broad as the cortical shell itself. In younger specimens the arms are often longer and more narrow. A delicate patagium is sometimes preserved between the arms.

\section{Lithocyclia cf. L. crux Moore, var. C Plate P6, fig. 1}

Remarks: This form is very similar to Lithocyclia cf. $L$. crux Moore, var. B; however, it has only three relatively short spongy arms. It occurs rarely and discontinuously in the upper part (mid-Oligocene) of the sections studied.

\section{Lithocyclia ocellus Ehrenberg group Plate P6, fig. 2}

Lithocyclia ocellus Ehrenberg, 1854, pl. 36, fig. 30; 1873, p. 240; Riedel and Sanfilippo, 1970, p. 522, pl. 5, figs. 1, 2

\section{Lophocyrtis (Cyclampterium) hadra Riedel and Sanfilippo Plate P6, figs. 3, 4}

Lophocyrtis hadra Riedel and Sanfilippo, 1986, p. 168, pl. 7, figs. $12-15$

Lophocyrtis (Cyclampterium) hadra (Riedel and Sanfilippo), Sanfilippo, 1990, p. 304, pl. I, figs. 11, 12

\section{Lophocyrtis (Cyclampterium) milowi (Riedel and Sanfilippo) \\ Plate P6, figs. 6, 7}

Cyclampterium ? milowi Riedel and Sanfilippo, 1971, p. 1593, pl. 3B, fig. 3; pl. 7, figs. 8, 9; 1978, p. 67, pl. 4, fig. 14; Ling, 1975, p. 731, pl. 12, fig. 15

Lophocyrtis (Cyclampterium) milowi (Riedel and Sanfilippo), Sanfilippo, 1990, p. 306, pl. I, figs. 13-16; pl. II, figs. 1, 2 
Remarks: The morphology of this species is highly variable and evolves through its relatively long range to a more open, less silicified thorax. As stated by Sanfilippo (1990), it appears to evolve from $L$. (C.) hadra; however, we see the transition occurring within the Cryptocarpium ornatum Zone (RP19), the uppermost Eocene.

\section{Lophocyrtis (Lophocyrtis) exitelus Sanfilippo}

Lophocyrtis (Lophocyrtis) exitelus Sanfilippo, 1990, p. 300, pl. I, figs. 1-4

Remarks: This species was very rare in the material studied.

\section{Lophocyrtis (Lophocyrtis) jacchia (Ehrenberg)} Plate P6, fig. 5

Thyrsocyrtis jacchia Ehrenberg, 1873, p. 261; 1875, pl. 12, fig. 7

Lophocyrtis (?) jacchia (Ehrenberg), Riedel and Sanfilippo, 1970, p. 530; 1971, p. 1594, pl. 3C, figs. 4, 5; pl. 7, fig. 16

Lophocyrtis (Lophocyrtis) jacchia (Ehrenberg), Sanfilippo, 1990, p. 302, pl. I, figs.5-10; pl. III, fig. 6

\section{Lophocyrtis (Sciadiopeplus) oberhaensliae Sanfilippo \\ Plate P6, figs. 8, 9}

Lophocyrtis (Sciadiopeplus) oberhaensliae Sanfilippo, 1990, p. 310, pl. II, figs. 10-14

Remarks: Only the late forms of this species (Sanfilippo, 1990, pl. 11, fig. 14) were clearly identified in this study, and then only as fragments. They first appear in the uppermost Eocene, shortly after the first appearance of $L$. milowi. Their last occurrence extends slightly beyond the last appearance of Dorcadospyris pseudopapilio and overlaps briefly with the earliest appearance of $D$. spinosa.

\section{Lychnocanoma amphitrite Foreman}

Plate P7, figs. 1, 2

Lychnocanoma amphitrite Foreman, 1973, p. 437, pl. 11, fig. 10

\section{Lychnocanoma babylonis (Clark and Campbell) group} Plate P7, fig. 3

Dictyophimus babylonis Clark and Campbell, 1942, p. 67, pl. 9, figs. 32, 36

Lychnocanoma babylonis (Clark and Campbell) group, Foreman, 1973 , p. 437 , pl. 2 , fig. 1

\section{Lychnocanoma turgidum (Ehrenberg) Plate P7, fig. 4}

Lychnocanium turgidum Ehrenberg, 1873, p. 245; 1875, pl. 7, fig. 6
[?] Lychnocanium pyriforme Haeckel, 1887, p. 1225, pl. 61, fig. 11 Gen. et sp. Indet.; Riedel and Sanfilippo, 1970, pl. 8, fig. 10

Lithochytris (Lithochytroides) turgidulum (sic) (Ehrenberg), Petrushevskaya and Kozlova, 1972, p. 552, pl. 27, figs. 8,9

Lithochytris sp. T, Petrushevskaya and Kozlova, 1972, p. 552 , pl. 27, fig. 6

Sethochytris cavipodis O'Connor, 1999, p. 28, pl. 4, figs. 2227; pl. 7, figs. $24 \mathrm{a}-27$

Lychnocanoma turgidum (Ehrenberg), Nigrini et al., 2006, p. 44, pl. P4, fig. 6

\section{Podocyrtis (Lampterium) chalara Riedel and Sanfilippo} Plate P7, fig. 8

Podocyrtis (Lampterium) chalara Riedel and Sanfilippo, 1970, p. 535, pl. 12, figs. 2, 3; Riedel and Sanfilippo, 1978 , p. 71 , pl. 8 , fig. 3 ; text-fig. 3

\section{Podocyrtis (Lampterium) goetheana (Haeckel)} Plate P7, fig. 9

Cycladophora goetheana Haeckel, 1887, p. 1376, pl. 65, fig. 5 Podocyrtis (Lampterium) goetheana (Haeckel), Riedel and Sanfilippo, 1970, p. 535; Nigrini et al., 2006, p. 45, pl. P5, figs. 11, 12

\section{Podocyrtis (Lampterium) mitra Ehrenberg}

Podocyrtis mitra Ehrenberg, 1854, pl. 36, fig. B20; 1873, p. 251; non Ehrenberg, 1875, pl. 15, fig. 4; Riedel and Sanfilippo, 1970 , p. 534, pl. 11, figs. 5, 6; 1978, text-fig. 3; Sanfilippo et al., 1985, p. 698, fig. 30.10

Remarks: This study did not sample material within the stratigraphic range of this species; however, specimens were found in our samples along with other reworked, older microfossils.

\section{Podocyrtis (Lampterium) trachodes Riedel and Sanfilippo \\ Plate P7, fig. 5}

Podocyrtis (Lampterium) trachodes Riedel and Sanfilippo, 1970, p. 535, pl. 11, fig. 7; pl. 12, fig. 1; Sanfilippo et al., 1985 , p. 699 , fig. 30.14

Remarks: This study did not sample material within the stratigraphic range of this species; however, specimens were found in our samples (especially Site U1333) along with other reworked, older microfossils.

\section{Podocyrtis (Podocyrtis) papalis Ehrenberg Plate P7, fig. 6}

Podocyrtis papalis Ehrenberg, 1847, p. 55, fig. 2; Riedel and Sanfilippo, 1970, p. 533, pl. 11, fig. 1; Sanfilippo and Riedel, 1973, p. 531, pl. 20, figs. 11-14; pl. 36, figs. 2, 3

Podocyrtis (Podocyrtis) papalis Ehrenberg, Nigrini et al., 2006, p. 46, pl. P5, fig. 13 
Podocyrtis (Podocyrtopsis) apeza Sanfilippo and Riedel Plate P7, fig. 7

Podocyrtis (Podocyrtopsis) apeza Sanfilippo and Riedel, 1992, p. 14 , pl. 3 , figs. $13-15$

\section{Pteropilium sp. aff. Pterocanium contiguum (Ehrenberg)} Plate P7, fig. 15

?Pterocanium contiguum Ehrenberg, 1873, p. 255; 1875, pl. 17, fig. 7

Pteropilium? sp. aff. Pterocanium contiguum Petrushevskaya and Kozlova, 1972, pl. 29, figs. 8-10

Pteropilium sp. O'Connor, 1999, p. 36, pl. 9, fig. 39

Pteropilium sp. aff. Pterocanium contiguum (Ehrenberg), Nigrini et al., 2006, p. 47, pl. P5, fig. 2

Remarks: This very rare species is most consistently found in the uppermost Eocene and lower Oligocene; however, a few specimens were found well below the E/O boundary.

\section{Rhopalocanium ornatum Ehrenberg Plate P7, fig. 13}

Rhopalocanium ornatum Ehrenberg, 1847, fig. 3; 1854, pl. 36, fig. 9; 1873, p. 256; 1875, pl. 17, fig. 8; Foreman, 1973, p. 439, pl. 2, figs. 8-10; pl. 12, fig. 3; Nigrini et al., 2006, p. 47 , pl. P4, figs. 15,16

\section{Sethochytris triconiscus Haeckel}

Plate P7, fig. 14

[?] Sethochytris triconiscus Haeckel, 1887, p. 1239, pl. 57, fig. 13; Riedel and Sanfilippo, 1970, p. 528, pl. 9, figs. 5, 6; Sanfilippo et al., 1985 , p. 680 , fig. $22.1 \mathrm{a}-22.1 \mathrm{~d}$

Remarks: This study did not sample material within the stratigraphic range of this species; however, specimens were found in our samples along with other reworked, older microfossils.

\section{Spongatractus pachystylus (Ehrenberg) Plate P7, fig. 10}

Spongosphaera pachystyla Ehrenberg, 1873, p. 256; 1875, pl. 26 , fig. 3

Spongatractus pachystylus (Ehrenberg), Sanfilippo and Riedel, 1973, p. 519, pl. 2, figs. 4-6; pl. 25, fig. 3

\section{Theocorys puriri O'Connor Plate P7, figs. 11, 12}

Theocorys puriri O'Connor, 1997, p. 88, pl. 4, figs. 5-8; pl. 10, figs. 5-8; pl. 11, fig. 7; Nigrini et al., 2006, p. 48, pl. P4, figs. 17, 18

Remarks: In the samples studied we found this species to range downward into the lowermost Oligocene with its first occurrence near that of Theocyrtis tuberosa. Because the distinctive abdomen of this species does not always preserve well and because there are several other species with a similar cephalis and thorax, it is often difficult to identify it in only moderately preserved samples. In such samples, the lack of a distinct collar stricture and a somewhat oblate cephalis are distinctive.

\section{Theocorys spongoconus Kling Plate P7, figs. 17, 18}

Theocorys spongoconus Kling, 1971, p. 1087, pl. 5, fig. 6; Nigrini et al., 2006, p. 48, pl. P4, figs. 19-21

Remarks: This species appears slightly after the first appearance of Theocorys puriri, which we believe is its ancestor.

\section{Theocotylissa ficus (Ehrenberg) \\ Plate P7, fig. 16}

Eucyrtidium ficus Ehrenberg, 1873, p. 228; 1875, pl. 11, fig. 19

Theocotylissa ficus (Ehrenberg), Sanfilippo and Riedel, 1982, p. 180, pl. 2, figs. 19, 20; Nigrini et al., 2006, p. 49 , pl. P5, fig. 1

\section{Theocyrtis careotuberosa Nigrini and Sanfilippo Plate P8, fig. 1}

Theocyrtis tuberosa Riedel, Riedel and Sanfilippo, 1970, pl. 13 , figs. 9,10

Theocyrtis sp. aff. T. tuberosa Riedel, Riedel and Sanfilippo, 1971, pl. 3D, figs. 16-18

Theocyrtis tuberosa Sanfilippo et al., 1985, fig. 32.1a, 32.1b; Saunders et al., 1984, pl. 5, fig. 10 (only)

Theocyrtis careotuberosa Nigrini and Sanfilippo, in Nigrini et al., 2006, p. 50-51, pl. P5, figs. 15-18

\section{Thyrsocyrtis aff. T. careotuberosa Nigrini and Sanfilippo} Plate P8, figs. 2, 3

Remarks: This form is similar to T. careotuberosa but is devoid of plicae. Its range starts near the disappearance of $T$. careotuberosa and ends below the last occurrence of $T$. $t u$ berosa. It is likely that $T$. careotuberosa is its ancestor.

\section{Theocyrtis perpumila Sanfilippo Plate P8, fig. 4}

Theocyrtis sp. Sanfilippo and Riedel, 1992, pl. 1, fig. 23 (only); (see also same reference, pl. 1, figs. 20-22)

Theocyrtis perpumila Sanfilippo, in Nigrini et al., 2006, p. 51, pl. P5, figs. 19-22

Theocyrtis tuberosa Riedel, emend. Sanfilippo et al. Plate P8, figs. 5, 6

Theocyrtis tuberosa Riedel, 1959, p. 298, pl. 2, figs. 10, 11; Sanfilippo et al., 1985, p. 701, fig. 32.1a-32.1d; Nigrini et al., 2006, p. 53, pl. P6, fig. 6

Remarks: Early forms are difficult to distinguish from $T$. careotuberosa, its ancestor-especially if the plicae on $T$. careotuberosa are corroded. However, the thoracic pores on T. careotuberosa are usually (but not always) uniformly circular in shape and longitudinally aligned with plicae pres- 
ent as a sharp thickening of the shell between pore rows, whereas in the early forms of $T$. tuberosa the thoracic pores tend to be more irregular in alignment and shape-especially in the lower part of the thorax.

\section{Thyrsocyrtis (Pentalacorys) krooni Sanfilippo and Blome Plate P8, figs. 7, 8}

Thyrsocyrtis tetracantha (Ehrenberg), Riedel and Sanfilippo, 1970, p. 527 (partim); Riedel and Sanfilippo, 1978, p. 81 (partim), pl. 10, fig. 9

Thyrsocyrtis (Pentalacorys) tetracantha (Ehrenberg), Sanfilippo and Riedel, 1982, p. 176 (in part), pl. 1, fig. 11; Sanfilippo et al., 1985, p. 690 (partim), fig. 26.8b

Thyrsocyrtis (Pentalacorys) krooni Sanfilippo and Blome, 2001, p. 207, fig. 7a-7e

Remarks: $T$. (P.) krooni first appears before either $T$. (P.) tetracantha or $T$. (P.) orthotenses and, as indicated by Sanfilippo and Blome (2001), probably derives from $T$. (P.) triacantha. See comments under $T$. (P.) tetracantha

\section{Thyrsocyrtis (Pentalacorys) lochites Sanfilippo and Riedel \\ Plate P8, figs. 9, 10}

Thyrsocyrtis (Pentalacorys) lochites Sanfilippo and Riedel, 1982, p. 175, pl. 1, fig. 13; pl. 3, figs. 5-9

\section{Thyrsocyrtis aff. T. (Pentalacorys) lochites Sanfilippo and Riedel}

Plate P8, figs. 11, 12

Remarks: As noted in Nigrini et al. (2006), "rare thickwalled forms with tubercles on the thorax and/or abdomen were observed in the early part of range of T. lochites." We believe this form not only overlaps the range of $T$. lochites but is the ancestor of T. lochites and extends somewhat below its range.

\section{Thyrsocyrtis (Pentalacorys) orthotenes Sanfilippo} Plate P8, fig. 13

Thyrsocyrtis sp. Petrushevskaya and Kozlova, 1972, pl. 34, fig. 5

Thyrsocyrtis (Pentalacorys) orthotenes Sanfilippo, in Nigrini et al., 2006, p. 54-55, pl. P5, figs. 4-5 (not fig. 3)

Remarks: in this study we exclude forms that have thoracic and abdominal pore structure and feet more similar to T. (P.) triacantha (Nigrini et al., 2006, pl. P5, fig. 3). By restricting the taxonomic usage in this manner we can define the first appearance of this species within Zone RP16. In the admittedly limited stratigraphic range of this study we cannot follow the line of evolutionary change that is outlined in Nigrini et al. (2006, p. 55). We do not find forms that clearly belong to this species (as used here) in the oldest samples studied. However we do note that the $T$. (P.) orthotenses having large abdominal pores (Nigrini et al., 2006, pl. P5, figs. 4-5) first appear slightly above the first appearance of $T$. (P.) tetracantha, suggesting that this form may derive from $T$. (P.) tetracantha or $T$. (P.) triacantha (see remarks under $T$. (P.) tetracantha). In this restricted sense, $T$. (P.) orthotenses has similar pore size and structure to those of T. (P.) tetracantha; however, it can be distinguished by its three (only) straight, downwardly directed feet.

\section{Thyrsocyrtis (Pentalacorys) tetracantha (Ehrenberg)} Plate P8, figs. 14, 15

Podocyrtis tetracantha Ehrenberg, 1873, p. 254; 1875, pl. 13, fig. 2

Thyrsocyrtis (Pentalacorys) tetracantha (Ehrenberg), Sanfilippo and Riedel, 1982, p. 176, pl. 1, figs. 11, 12; pl. 3, fig. 10

Remarks: The first appearances of $T$. (P.) tetracantha and $T$. (P.) orthotenses are marked by considerable variability in their morphology. In some cases, a specimen will show two or three strong cylindrical feet with another "foot," more consistent with the termination of T. krooni. In other cases there are multiple shorter, more delicate feet extending from an abdominal termination that otherwise resembles $T$. krooni. In the case of the earliest appearance of $T$. (P.) orthotenses, $T$. (P.) tetracantha can often show very straight, thick cylindrical feet typical of $T$. (P.) orthotenses, but having four feet (rather than three) in number. In addition, when $T$. (P.) tetracantha terminates with three thick cylindrical feet, two may be straight in the style of $T$. (P.) orthotenses, whereas the third foot deviates in some way from straight down. It seems possible that both $T$. (P.) tetracantha and T. (P.) orthotensis derive from T. (P.) krooni, either directly or with $T$. (P.) krooni giving rise to $T$. (P.) tetracantha, which in turn gave rise to $T$. (P.) orthotenses.

\section{Thyrsocyrtis (Pentalacorys) triacantha (Ehrenberg) Plate P9, figs. 1, 2}

Podocyrtis triacantha Ehrenberg, 1873, p. 254; 1875, pl. 13, fig. 4

Thyrsocyrtis (Pentalacorys) triacantha (Ehrenberg), Sanfilippo and Riedel, 1982, p. 176, pl. 1, figs. 8-10; pl. 3, figs. 3,4

\section{Thyrsocyrtis (Thyrsocyrtis) bromia Ehrenberg group Plate P9, figs. 3-10}

Thyrsocyrtis bromia Ehrenberg, 1873, p. 260; 1875, pl. 12, fig. 2; Sanfilippo and Riedel, 1982, p. 172, pl. 1, figs. 1720

Remarks: This species has a rather broad definition, particularly regarding pore size in the abdomen (Sanfilippo and Riedel, 1982). This has probably led to some misunderstanding regarding its taxonomy and its stratigraphic range. O'Connor discusses these problems in his description of Thyrsocyrtis (Thyrsocyrtis) pinguisicoides (O'Connor, 1999, p. 29-30), in which he disinguishes this new species as a form with smaller abdominal pores than what he considers to be $T$. (T.) bromia. It appears from our study that $T$. (T.) bromia, even if restricted to specimens with large abdominal pores, may represent at least two separate lineages. Our observations suggest that early in its development $T$. (T.) bromia may derive from $T$. (T.) krooni, with intermediate forms having a somewhat wavy peri- 
stome and a smooth, elongate conical apical horn. This form increases in abundance upsection (Tables T2, T3, T4, T5, T6, and T7) and then decreases, being replaced by a similar form with large abdominal pores, three short, toothlike feet, and an apical horn that may be roughened or thorny distally. This form becomes quite common upsection. The ancestor of this form may be Thyrsocyrtis (Thyrsocyrtis) cf. T. (T.) norrisi, through one or more intermediate forms (Thyrsocyrtis (Thyrsocyrtis) aff. T. (T.) pinguisicoides or Thyrsocyrtis (Thyrsocyrtis) pinguisicoides, see below).

\section{Thyrsocyrtis (Thyrsocyrtis) cf. T. (T.) norrisi Sanfilippo and Blome \\ Plate P9, figs. 11, 12}

Thyrsocyrtis bromia, Dinkleman, 1973, p. 788, pl. 3. fig. 4 Thyrsocyrtis (Thyrsocyrtis) norrisi Sanfilippo and Blome, 2001, p. 207-208, fig. 7f-7j, 7l, 7m

Remarks: Thyrsocyrtis (Thyrsocyrtis) norrisi was described from the tropical Atlantic, ODP Site 1051, and was not identified in our Pacific samples. The specimens figured herein and by Dinkelman (1973) have larger abdominal pores than any of the specimens illustrated by Sanfilippo and Blome (2001); however, the description of their new species allows for larger abdominal pores. The distal part of the apical horn is thorny, similar to $T$. (T.) norrisi. Although the peristome of this Pacific form is wide and hyaline, the feet are not particularly divergent. The form figured herein first occurs in the uppermost part of the Podocyrtis (Lampterium) goetheana Zone (RP16) (Tables T2, T3, T4, T5, T6, and T7), above the likely range of $T$. (T.) norrisi in the tropical Atlantic (Sanfilippo and Blome, 2001).

\section{Thyrsocyrtis (Thyrsocyrtis) pinguisicoides O'Connor Plate P9, figs. 13-16}

?Thyrsocyrtis sp. Dinkleman, 1973, p. 788, pl. 3. figs. 7, 8

Theocotyle "pinguisicoides" O'Connor, Hollis et al., 1997, p. 65. pl. 6, figs. 10-12 (nom. nud.).

Thyrsocyrtis (Thyrsocyrtis) pinguisicoides O'Connor, 1999, p. 29-30, pl. 4, figs. 28-32; pl. 7, figs. 28a-31

Remarks: O'Connor (1999) gives a long discussion of this species and its taxonomy as it is defined in samples from South Island, New Zealand. He notes that the forms illustrated by Dinkleman (1973) "have more irregularly arranged thoracic pores, a differently shaped thorax, and a wider abdomen with respect to the thorax," and thus only tentatively includes this form in $T$. (T.) pinguisicoides. Here we accept this inclusion with some reservations. Specimens of this form in the samples studied occur in a stratigraphic position similar to that found by Dinkleman (1973) and O'Connor (1999). However, in addition to the differences mentioned above in the form illustrated by Dinkleman (1973), we also note that many specimens (but not all) have small toothlike feet projecting from the peristomal ring (Plate P9, fig. 13). Later in the development of this form the feet disappear and are replaced by a more delicate, very irregularly pored or spongy termination that is rarely well preserved. (Plate P9, figs. 15, 16). This exten- sion is similar to the termination of Artophormis gracilis but appears to be more coarsely pored. Tiny, hairlike attachments to the peristome detectable in the Dinkleman (1973) illustrations may be remnants of this spongy apron. The small toothlike projections in the early specimens and the thorny character of the apical horn may indicate that this species is descended from Thyrsocyrtis (Thyrsocyrtis) cf. $T$. (T.) norrisi (see above), perhaps through the intermediate form Thyrsocyrtis (Thyrsocyrtis) aff. T. (T.) pinguisicoides (see below).

\section{Thyrsocyrtis (Thyrsocyrtis) aff. T. (T.) pinguisicoides O'Connor \\ Plate P9, figs. 17-19}

Remarks: This very robust form first appears just above the first appearance of Thyrsocyrtis (Thyrsocyrtis) cf. T. (T.) norrisi and has a few similar characteristics. The cephalis bears a stout apical horn that is often as wide as the cephalis itself. The horn is bladed proximally but becomes cylindrical a short distance above the cephalis and is roughened and thorny distally, similar to Thyrsocyrtis (Thyrsocyrtis) cf. T. (T.) norrisi. Also similar is a distinct hyaline peristome with three triangular feet extending from it. The thorax has relatively small, hexagonally arranged pores; however, these pores do vary in size and shape and thus make the arrangement less than perfectly regular. Spines are frequently preserved extending outward from the pore bars of the thorax. The abdomen is inflated to subcylindrical. The abdominal pores are two to more than four times larger than those of the thorax, but they are highly irregular in size, shape, and arrangement. Pore bars in the thorax are laterally compressed so that their radial thickness is distinctly greater than their lateral thickness. A thin ridge is often seen on the outer pore bars, from which rise numerous small spines. Larger spines or nodes are present at pore bar junctions. Remnants of a delicate, spongy extension are often preserved along the edge of the peristome and peristomal feet. In the upper part of the range of this form, the peristomal feet become smaller and eventually disappear, leaving only remnants of the spongy extension along the peristome.

\section{Thyrsocyrtis (Thyrsocyrtis) rhizodon Ehrenberg Plate P10, fig. 1}

Thyrsocyrtis rhizodon Ehrenberg, 1873, p. 262; 1875, p. 94, pl. 12, fig. 1; Sanfilippo and Riedel, 1982, p. 173, pl. 1, figs. 14-16; pl. 3, figs. 12-17

\section{Tristylospyris triceros (Ehrenberg) Plate P10, figs. 2-4}

Ceratospyris triceros Ehrenberg, 1873, p. 220; 1875, pl. 21, fig. 5

Tristylospyris triceros (Ehrenberg), Haeckel, 1887, p. 1033; Riedel, 1959, p. 292, pl. 1, figs. 7, 8; Sanfilippo et al., 1985, p. 665, fig. 10.3a, 10.3b; Nigrini et al., 2006, p. 56, pl. P3, figs. 7,8 
Remarks: This species is used in a restricted sense herein to include forms bearing three cylindrical primary feet varying from slightly divergent to semicircularly curved and three or more secondary feet that are shorter and thinner, varying in form from cylindroconical to thin lamellar (Nigrini et al., 2006).

\section{Zealithapium cf. Z. anoectum (Riedel and Sanfilippo) Plate P10, figs. 6, 7}

Lithapium anoectum Riedel and Sanfilippo, 1973, p. 516, pl. 24, figs. 6, 7

Zealithapium anoectum (Riedel and Sanfilippo), O'Connor, 1999 , p. 5; Nigrini et al., 2006, p. 56, pl. P1, figs. 1-4

Remarks: This form was found sporadically in the upper Eocene by Nigrini et al. (2006), as it is here. In spite of its sporadic appearance in samples, is does seem to have a consistent last appearance datum (Table T8).

\section{Zealithapium mitra (Ehrenberg) Plate P10, fig. 5}

Cornutella mitra Ehrenberg, 1873, p. 221; 1875, pl. 2, fig. 8 Lithapium (?) mitra (Ehrenberg), Riedel and Sanfilippo, 1970 , p. 520 , pl. 4 , figs. 6,7

Zealithapium mitra (Riedel and Sanfilippo), O'Connor, 1999, pp. 5, 6, pl. 9, fig. 47

\section{Zygocircus cimelium Petrushevskaya Plate P10, figs. 8, 9}

Zygocircus cimelium Petrushevskaya, in Petrushevskaya and Kozlova, 1972, p. 534, pl. 41, figs. 5, 6; Nigrini et al., 2006, pp. 56-57, pl. P3, figs. 9-12

Remarks: Illustrations, remarks, and measurements contained in Nigrini et al. (2006) are very helpful in recognizing this species, which is often present only as fragments.

\section{Acknowledgments}

We are grateful to Prof. H. Pälike (University of Southampton) and Prof. H. Nishi (Tohoku University) for their leadership and guidance during and after IODP Expedition 320 and to other scientists and crew members of Expedition 320 for their help and support. Joanne Reuss provided invaluable laboratory assistance in preparing the samples used in this study. This work was financially supported by a contract with the Consortium for Ocean Leadership for the first author and a Grant-in-Aid for Research Fellowships of the Japan Society for the Promotion of Science for Young Scientists (number 20-1155) to the second author. We thank Annika Sanfilippo for reviewing the manuscript and providing useful comments.

\section{References}

Clark, B.L., and Campbell, A.S., 1942. Eocene radiolarian faunas from the Mt. Diablo area, California. Spec. Pap.Geol. Soc. Am., 39.

Coxall, H.K., Wilson, P.A., Pälike, H., Lear, C.H., and Backman, J., 2005. Rapid stepwise onset of Antarctic glaciation and deeper calcite compensation in the Pacific Ocean. Nature (London, U. K.), 433(7021):53-57. doi:10.1038/nature03135

Dinkelman, M.G., 1973. Radiolarian stratigraphy: Leg 16, Deep Sea Drilling Program. In van Andel, T.H., Heath, G.R., et al., Init. Repts. DSDP, 16: Washington, DC (U.S. Govt. Printing Office), 747-813. doi:10.2973/

dsdp.proc.16.128.1973

Ehrenberg, C.G., 1847. Über die mikroskopischen kieselschaligen Polycystinen als mächtige Gebirgsmasse von Barbados und über das Verhältniss deraus mehr als 300 neuen Arten bestehenden ganz eigenthümlichen Formengruppe jener Felsmasse zu den jetzt lebenden Thieren und zur Kreidebildung. Eine neue Anregung zur Erforschung des Erdlebens. K. Preuss. Akad. Wiss. Berlin, Ber., Jahre 1847:40-60.

Ehrenberg, C.G., 1854. Mikrogeologie: Das Erden und Felsen schaffende Wirken des unsichtbar kleinen selbständigen Lebens auf der Erde: Leipzig (Leopold Voss).

Ehrenberg, C.G., 1873. Grössere Felsproben des Polycystinen-Mergels von Barbados mit weiteren Erläuterungen. K. Preuss. Akad. Wiss. Berlin, Monatsber., 1873:213-263.

Ehrenberg, C.G., 1875. Fortsetzung der mikrogeologischen Studien als Gesammt-Uebersicht der mikroskopischen Paläontologie gleichartig analysirter Gebirgsarten der Erde, mit specieller Rücksicht auf den Polycystinen-Mergel von Barbados. Abh. K. Akad. Wiss. Berlin, 1875:1225.

Engebretson, D.C., Cox, A., and Gordon, R.G., 1985. Relative motions between oceanic and continental plates in the Pacific basin. Spec. Pap.—Geol. Soc. Am., 206.

Foreman, H.P., 1973. Radiolaria of Leg 10 with systematics and ranges for the families Amphipyndacidae, Artostrobiidae, and Theoperidae. In Worzel, J.L., Bryant, W., et al., Init. Repts. DSDP, 10: Washington, DC (U.S. Govt. Printing Office), 407-474. doi:10.2973/ dsdp.proc.10.118.1973

Funakawa, S., Nishi, H., Moore, T.C., and Nigrini, C.A., 2006. Radiolarian faunal turnover and paleoceanographic change around Eocene/Oligocene boundary in the central equatorial Pacific, ODP Leg 199, Holes 1218A, 1219A, and 1220A. Palaeogeogr., Palaeoclimatol., Palaeoecol., 230(3-4):183-203. doi:10.1016/j.palaeo.2005.07.014

Gripp, A.E., and Gordon, R.G., 1990. Current plate velocities relative to the hotspots incorporating the NUVEL-1 global plate motion model. Geophys. Res. Lett., 17(8):1109-1112. doi:10.1029/GL017i008p01109 
Haeckel, E., 1887. Report on the radiolaria collected by H.M.S. Challenger during the years 1873-1876. Report on the Scientific Results of the Voyage of H.M.S. Challenger during the years 1873-1876. Zoology, 18. http://caliban.mpiz-koeln.mpg.de/haeckel/challenger/

Hollis, C.J., Waghorn, D.B., Strong, C.P., and Crouch, E.M., 1997. Integrated Paleogene biostratigraphy of DSDP Site 277 (Leg 29): foraminifera, calcareous nannofossils, radiolaria, and palynomorphs. Ltd. Sci. Rep.-Inst. Geol. Nucl. Sci., 1-87.

Kling, S.A., 1971. Radiolaria: Leg 6 of the Deep Sea Drilling Project. In Fischer, A.G., Heezen, B.C., et al., Init. Repts. DSDP, 6: Washington, DC (U.S. Govt. Printing Office), 1069-1117. doi:10.2973/dsdp.proc.6.134.1971

Koppers, A.A.P., Phipps Morgan, J., Morgan, J.W., and Staudigel, H., 2001. Testing the fixed hotspot hypothesis using ${ }^{40} \mathrm{Ar} /{ }^{39} \mathrm{Ar}$ age progressions along seamount trails. Earth Planet. Sci. Lett., 185(3-4):237-252. doi:10.1016/ S0012-821X(00)00387-3

Ling, H.Y., 1975. Radiolaria: Leg 31 of the Deep Sea Drilling Project. In Karig, D.E., Ingle, J.C., Jr., et al., Init. Repts. DSDP, 31: Washington (U.S. Govt. Printing Office), 703-761. doi:10.2973/dsdp.proc.31.137.1975

Lyle, M., Wilson, P.A., Janecek, T.R., et al., 2002. Proc. ODP, Init. Repts., 199: College Station, TX (Ocean Drilling Program). doi:10.2973/odp.proc.ir.199.2002

Mato, C.Y., and Theyer, F., 1980. Lychnocanoma bandyca n. sp., a new stratigraphically important late Eocene radiolarian. In Sliter, W. V. (Ed.), Studies in Marine Micropaleontology and Paleoecology: A Memorial Volume to Orville L. Bandy. Spec. Publ. Cushman Found. Foraminiferal Res., 19:225-229.

Moore, T.C., 1971. Radiolaria. In Tracey, J.I., Jr., Sutton, G.H., et al., Init. Repts. DSDP, 8: Washington, DC (U.S. Govt. Printing Office), 727-775. doi:10.2973/ dsdp.proc.8.112.1971

Moore, T.C., Jr., 1973. Method of randomly distributing grains for microscopic examination. J. Sediment. Petrol., 43(3):904-906. doi:10.1306/74D728BA-2B21-11D78648000102C1865D

Moore, T.C., Jr., Backman, J., Raffi, I., Nigrini, C., Sanfilippo, A., Pälike, H., and Lyle, M., 2004. Paleogene tropical Pacific: clues to circulation, productivity, and plate motion. Paleoceanography, 19(3):PA3013. doi:10.1029/2003PA000998

Moore, T.C., Jr., Jarrard, R.D., Olivarez Lyle, A., and Lyle, M., 2008. Eocene biogenic silica accumulation rates at the Pacific equatorial divergence zone. Paleoceanography, 23(2):PA2202. doi:10.1029/2007PA001514

Moore, T.C., Jr., Shackleton, N.J., and Pisias, N.G., 1993. Paleoceanography and the diachrony of radiolarian events in the eastern equatorial Pacific. Paleoceanography, 8(5):567-586. doi:10.1029/93PA01328

Nigrini, C., 1977. Tropical Cenozoic Artostrobiidae (Radiolaria). Micropaleontology, 23(3):241-269. doi:10.2307/ 1485215

Nigrini, C., Sanfilippo, A., and Moore, T.C., Jr., 2006. Cenozoic radiolarian biostratigraphy: a magnetobiostratigraphic chronology of Cenozoic sequences from ODP Sites 1218, 1219, and 1220, equatorial Pacific. In Wil- son, P.A., Lyle, M., and Firth, J.V. (Eds.), Proc. ODP, Sci. Results, 199: College Station, TX (Ocean Drilling Program), 1-76. doi:10.2973/odp.proc.sr.199.225.2006

O'Connor, B., 1994. Seven new radiolarian species from the Oligocene of New Zealand. Micropaleontology, 40(4):337-350. doi:10.2307/1485939

O'Connor, B., 1997. New Radiolaria from the Oligocene and early Miocene of Northland, New Zealand. Micropaleontology, 43(1):63-100. doi:10.2307/1485923

O'Connor, B., 1999. Radiolaria from the late Eocene Oamaru diatomite, South Island, New Zealand. Micropaleontology, 45(1):1-55. doi:10.2307/1486201

Parés, J.M., and Moore, T.C., 2005. New evidence for the Hawaiian hotspot plume motion since the Eocene. Earth Planet. Sci. Lett., 237(3-4):951-959. doi:10.1016/ j.epsl.2005.06.012

Petrushevskaya, M.G., and Kozlova, G.E., 1972. Radiolaria: Leg 14, Deep Sea Drilling Project. In Hayes, D.E., Pimm, A.C., et al., Init. Repts. DSDP, 14: Washington, DC (U.S. Govt. Printing Office), 495-648. doi:10.2973/ dsdp.proc.14.116.1972

Pälike, H., Nishi, H., Lyle, M., Raffi, I., Gamage, K., Klaus, A., and the Expedition 320/321 Scientists, 2010. Expedition 320/321 summary. In Pälike, H., Lyle, M., Nishi, H., Raffi, I., Gamage, K., Klaus, A., and the Expedition 320/ 321 Scientists, Proc. IODP, 320/321: Tokyo (Integrated Ocean Drilling Program Management International, Inc.). doi:10.2204/iodp.proc.320321.101.2010

Riedel, W.R., 1959. Oligocene and lower Miocene Radiolaria in tropical Pacific sediments. Micropaleontology, 5(3):285-302. doi:10.2307/1484421

Riedel, W.R., and Sanfilippo, A., 1970. Radiolaria, Leg 4, Deep Sea Drilling Project. In Bader, R.G., Gerard, R.D., et al., Init. Repts. DSDP, 4: Washington, DC (U.S. Govt. Printing Office), 503-575. doi:10.2973/ dsdp.proc.4.124.1970

Riedel, W.R., and Sanfilippo, A., 1971. Cenozoic Radiolaria from the western tropical Pacific, Leg 7. In Winterer, E.L., Riedel, W.R., et al., Init. Repts. DSDP, 7: Washington, DC (U.S. Govt. Printing Office), 1529-1672. doi:10.2973/dsdp.proc.7.132.1971

Riedel, W.R., and Sanfilippo, A., 1978. Stratigraphy and evolution of tropical Cenozoic radiolarians. Micropaleontology, 24(1):61-96. doi:10.2307/1485420

Riedel, W.R., and Sanfilippo, A., 1986. Morphological characters for a natural classification of Cenozoic Radiolaria, reflecting phylogenies. Mar. Micropaleontol., 11(13):151-170. doi:10.1016/0377-8398(86)90011-3

Sager, W.W., and Pringle, M.S., 1988. Mid-Cretaceous to early Tertiary apparent polar wander path of the Pacific plate. J. Geophys. Res., [Solid Earth], 93(B10):1175311771. doi:10.1029/JB093iB10p11753

Sanfilippo, A., 1990. Origin of the subgenera Cyclampterium, Paralampterium and Sciadiopeplus from Lophocyrtis (Lophocyrtis) (Radiolaria, Theoperidae). Mar. Micropaleontol., 15(3-4):287-312. doi:10.1016/03778398(90)90016-F

Sanfilippo, A., and Blome, C.D., 2001. Biostratigraphic implications of mid-latitude Paleocene-Eocene radiolarian faunas from Hole 1051A, ODP Leg 171B, Blake 
Nose, western North Atlantic. In Kroon, D., Norris, R.D., and Klaus, A. (Eds.), Western North Atlantic Palaeogene and Cretaceous Palaeoceanography. Geol. Soc. Spec. Publ., 183(1):185-224. doi:10.1144/GSL.SP.2001.183.01.10

Sanfilippo, A., and Nigrini, C., 1995. Radiolarian stratigraphy across the Oligocene/Miocene transition. Mar. Micropaleontology, 24(3-4):239-285. doi:10.1016/03778398(94)00015-F

Sanfilippo, A., and Riedel, W.R., 1973. Cenozoic Radiolaria (exclusive of theoperids, artostrobiids and amphipyndacids) from the Gulf of Mexico, Deep Sea Drilling Project Leg 10. In Worzel, J.L., Bryant, W., et al., Init. Repts. DSDP, 10: Washington, DC (U.S. Govt. Printing Office), 475-611. doi:10.2973/dsdp.proc.10.119.1973

Sanfilippo, A., and Riedel, W.R., 1982. Revision of the radiolarian genera Theocotyle, Theocotylissa, and Thyrsocyrtis. Micropaleontology, 28(2):170-188. doi:10.2307/1485229

Sanfilippo, A., and Riedel, W.R., 1992. The origin and evolution of Pterocorythidae (Radiolaria): a Cenozoic phylogenetic study. Micropaleontology, 38(1):1-36. doi:10.2307/1485841

Sanfilippo, A., Westberg-Smith, M.J., and Riedel, W.R., 1985. Cenozoic Radiolaria. In Bolli, H.M., Saunders, J.B., and Perch-Nielsen, K. (Eds.), Plankton Stratigraphy: Cambridge (Cambridge Univ. Press), 631-712.
Saunders, J.B., Bernoulli, D., Müller-Merz, E., Oberhänsli, H., Perch-Nielsen, K., Riedel, W.R., Sanfilippo, A., and Torrini, R., Jr., 1984. Stratigraphy of later middle Eocene to early Oligocene in Bath Cliff section, Barbados, West Indies. Micropaleontology, 30(4):390-425. doi:10.2307/ 1485710

Westerhold, T., Röhl, U., Wilkens, R., Pälike, H., Lyle, M., Jones, T.D., Bown, P., Moore, T., Kamikuri, S., Acton, G., Ohneiser, C., Yamamoto, Y., Richter, C., Fitch, P., Scher, H., Liebrand, D., and the Expedition 320/321 Scientists, 2012. Revised composite depth scales and integration of IODP Sites U1331-U1334 and ODP Sites 1218-1220. In Pälike, H., Lyle, M., Nishi, H., Raffi, I., Gamage, K., Klaus, A., and the Expedition 320/321 Scientists, Proc. IODP, 320/321: Tokyo (Integrated Ocean Drilling Program Management International, Inc.). doi:10.2204/ iodp.proc.320321.201.2012

Initial receipt: 6 December 2011

Acceptance: 23 March 2012

Publication: 24 August 2012

MS 320321-204 
Figure F1. Location of IODP Sites U1333 and U1334 and ODP Site 1218 (red stars) used in this study. Other Expedition 320/321 site locations are shown as red circles. Other ODP and Deep Sea Drilling Project (DSDP) site locations in the region are shown as black circles. F.Z. = fracture zone.

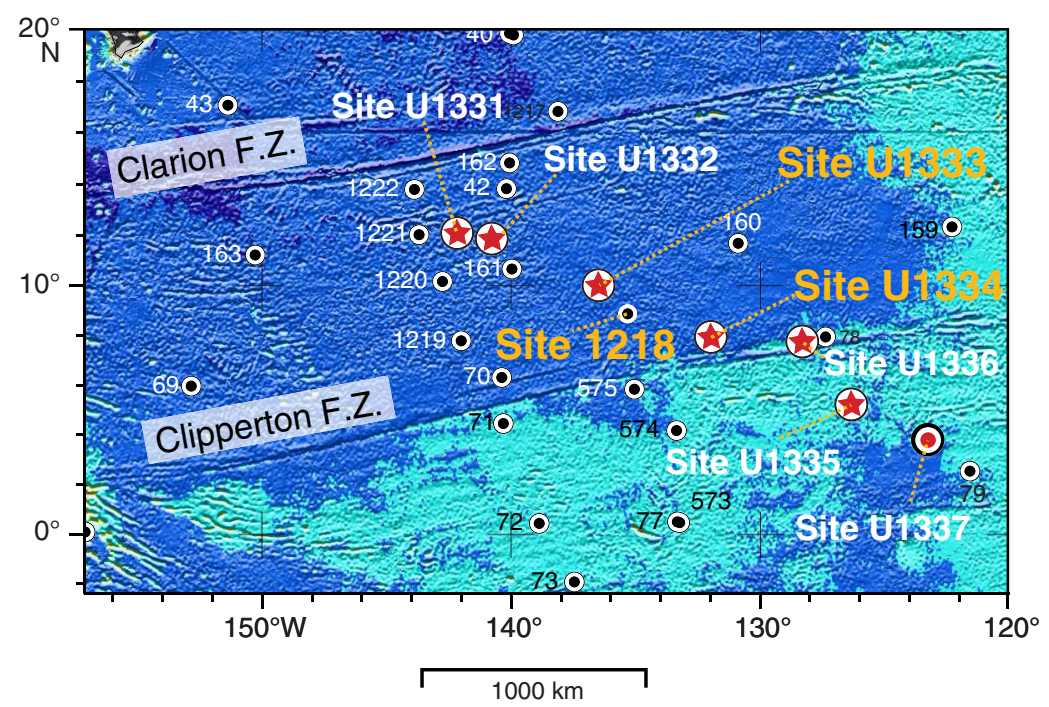


Table T1. Paleolatitude position of ODP Site 1218 and IODP Sites U1333 and U1334 calculated using the models employed during ODP Leg 199 (Lyle et al., 2002) and IODP Expedition 320 (Pälike et al., 2010) and as corrected for tilt of the equatorial axis of sediment accumulation rates (P\&M; Parés and Moore, 2005). All paleolatitudes are in degrees north (+) or south (-).

\begin{tabular}{|c|c|c|c|c|c|c|c|c|c|}
\hline \multirow{2}{*}{$\begin{array}{l}\text { Age } \\
\text { (Ma) }\end{array}$} & \multicolumn{3}{|c|}{ Site 1218} & \multicolumn{3}{|c|}{ Site U1334 } & \multicolumn{3}{|c|}{ Site U1333 } \\
\hline & Leg 199 & Exp 320 & P\&M & Leg 199 & Exp 320 & P\&M & Leg 199 & Exp 320 & P\&M \\
\hline 30 & 1.612 & 1.45 & 2.8576 & 1.114 & 0.78 & 2.344 & 2.905 & 2.90 & 4.198 \\
\hline 31 & 1.445 & 1.27 & 2.64087 & 0.958 & 0.61 & 2.186 & 2.728 & 2.71 & 3.944 \\
\hline 32 & 1.280 & 1.09 & 2.42414 & 0.804 & 0.44 & 2.029 & 2.553 & 2.53 & 3.691 \\
\hline 33 & 1.117 & 0.92 & 2.20741 & 0.653 & 0.28 & 1.872 & 2.380 & 2.35 & 3.437 \\
\hline 34 & 0.956 & 0.74 & 1.99068 & 0.504 & 0.11 & 1.715 & 2.209 & 2.16 & 3.184 \\
\hline 35 & 0.798 & 0.57 & 1.77395 & 0.357 & -0.05 & 1.557 & 2.040 & 1.98 & 2.930 \\
\hline 36 & 0.641 & 0.40 & 1.55722 & 0.212 & -0.22 & 1.400 & 1.873 & 1.80 & 2.676 \\
\hline 37 & 0.487 & 0.23 & 1.34049 & 0.070 & -0.38 & 1.243 & 1.708 & 1.62 & 2.423 \\
\hline 38 & 0.335 & 0.06 & 1.12376 & -0.070 & -0.54 & 1.086 & 1.545 & 1.45 & 2.169 \\
\hline 39 & 0.185 & -0.11 & 0.90703 & -0.207 & -0.70 & 0.928 & 1.384 & 1.27 & 1.915 \\
\hline 40 & 0.037 & -0.27 & 0.6903 & -0.343 & -0.86 & 0.771 & 1.226 & 1.09 & 1.662 \\
\hline
\end{tabular}

Table T2. Abundance of radiolarians (counts), ODP Site 1218 (see "Methods and materials"), arranged in order of corrected adjusted revised meters composite depth (rmcd) (Westerhold et al., 2012). This table is available in an oversized format.

Table T3. Abundance of radiolarians (ppt), ODP Site 1218 (see "Methods and materials"), arranged in order of corrected adjusted revised meters composite depth (rmcd) (Westerhold et al., 2012). This table is available in an oversized format.

Table T4. Abundance of radiolarians (counts), IODP Site U1333 (see "Methods and materials"), arranged in order of corrected adjusted revised meters composite depth (rmcd) at ODP Site 1218 (Westerhold et al., 2012). This table is available in an oversized format.

Table T5. Abundance of radiolarians (ppt), IODP Site U1333 (see "Methods and materials"), arranged in order of corrected adjusted revised meters composite depth (rmcd) at ODP Site 1218 (Westerhold et al., 2012). This table is available in an oversized format.

Table T6. Abundance of radiolarians (counts), Site U1334 (see "Methods and materials"), arranged in order of corrected adjusted revised meters composite depth (rmcd) at ODP Site 1218 (Westerhold et al., 2012). This table is available in an oversized format.

Table T7. Abundance of radiolarians (ppt), Site U1334 (see "Methods and materials"), arranged in order of corrected adjusted revised meters composite depth (rmcd) at ODP Site 1218 (Westerhold et al., 2012). This table is available in an oversized format.

Table T8. Species first appearance datums (FAD) and last appearance datums (LAD) for ODP Site 1218 and IODP Sites U1333 and U1334. This table is available in an oversized format. 
Plate P1. Anthocyrtoma through Centrobotrys. All scale bars $=50 \mathrm{~mm}$. Sample depths are corrected and adjusted corresponding to depths (revised meters composite depth [rmcd]) in ODP Site 1218 (from Westerhold et al., 2012). (Plate shown on next page.)

1. Anthocyrtoma spp. (Sample 320-U1333A-15X-1, 80-81 cm; $262.39 \mathrm{rmcd}$ ).

2. Artophormis barbadensis (Ehrenberg) (Sample 199-1218B-25X-2, 100-101 cm; $253.21 \mathrm{rmcd}$ ).

3. Artophormis dominasinensis (Ehrenberg) (Sample 320-U1333A-14X-6, 140-141 cm; $259.03 \mathrm{rmcd}$ ).

4. Artophormis gracilis Riedel (Sample 320-U1333B-12H-4, 100-101 cm; 229.95 rmcd).

5. Calocyclas bandyca (Mato and Theyer) with four feet, three of the feet are broken (Sample 199-1218B-25X-2, $100-101 \mathrm{~cm} ; 253.21 \mathrm{rmcd})$.

6. Calocyclas bandyca (Mato and Theyer) with three feet (Sample 320-U1333C-15H-2, 30-31cm; $249.60 \mathrm{rmcd}$ ).

7. Calocyclas hispida (Ehrenberg) (Sample 320-U1333A-15X-1, 80-81 cm; 268.39 rmcd).

8. Calocyclas hispida (Ehrenberg) (Sample 320-U1333A-15X-4, 96-98 cm; $258.60 \mathrm{rmcd}$ ).

9. Calocyclas turris Ehrenberg (Sample 199-1218B-26X-3, 73-74 cm; $249.60 \mathrm{rmcd}$ ).

10. Calocyclas turris Ehrenberg (Sample 320-U1333C-15H-2, 30-31 cm; $249.60 \mathrm{rmcd}$ ).

11. Calocycletta (Calocycletta) anekathen Sanfilippo and Nigrini (Sample 320-U1334C-28X-4, 40-41 cm; 245.07 rmcd).

12. Calocycloma ampulla (Ehrenberg) (Sample 320-U1333A-15X-2, 143-144 cm; $264.10 \mathrm{rmcd}$ ).

13. Centrobotrys gravida Moore (Sample 320-U1333B-12H-4, 0-1 cm; $228.98 \mathrm{rmcd}$ ).

14. Centrobotrys petrushevskayae Sanfilippo and Riedel (Sample 320-U1333C-11H-5, 100-101 cm; $211.80 \mathrm{rmcd}$ ). 
Plate P1 (continued). (Caption shown on previous page.)
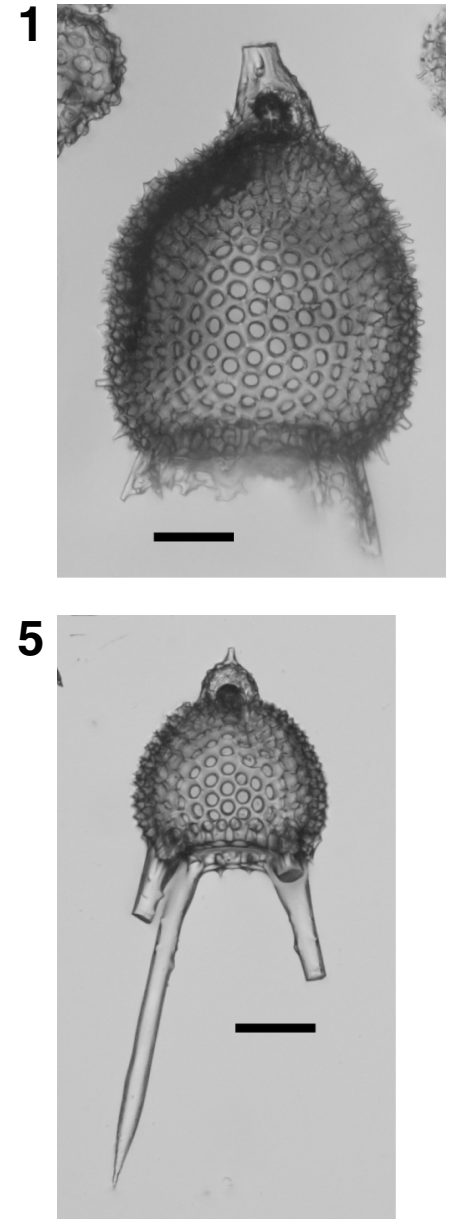

8

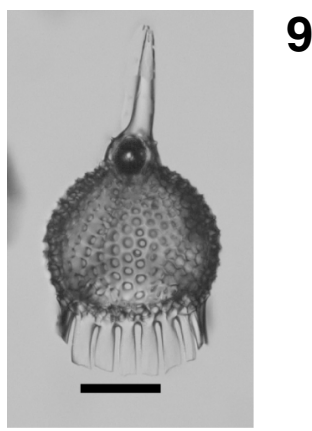

9
2

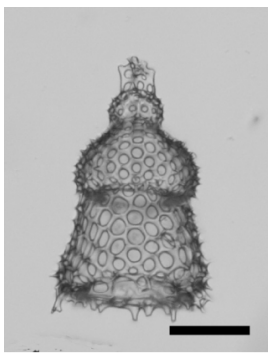

3

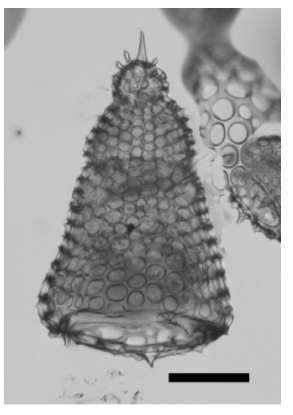

6
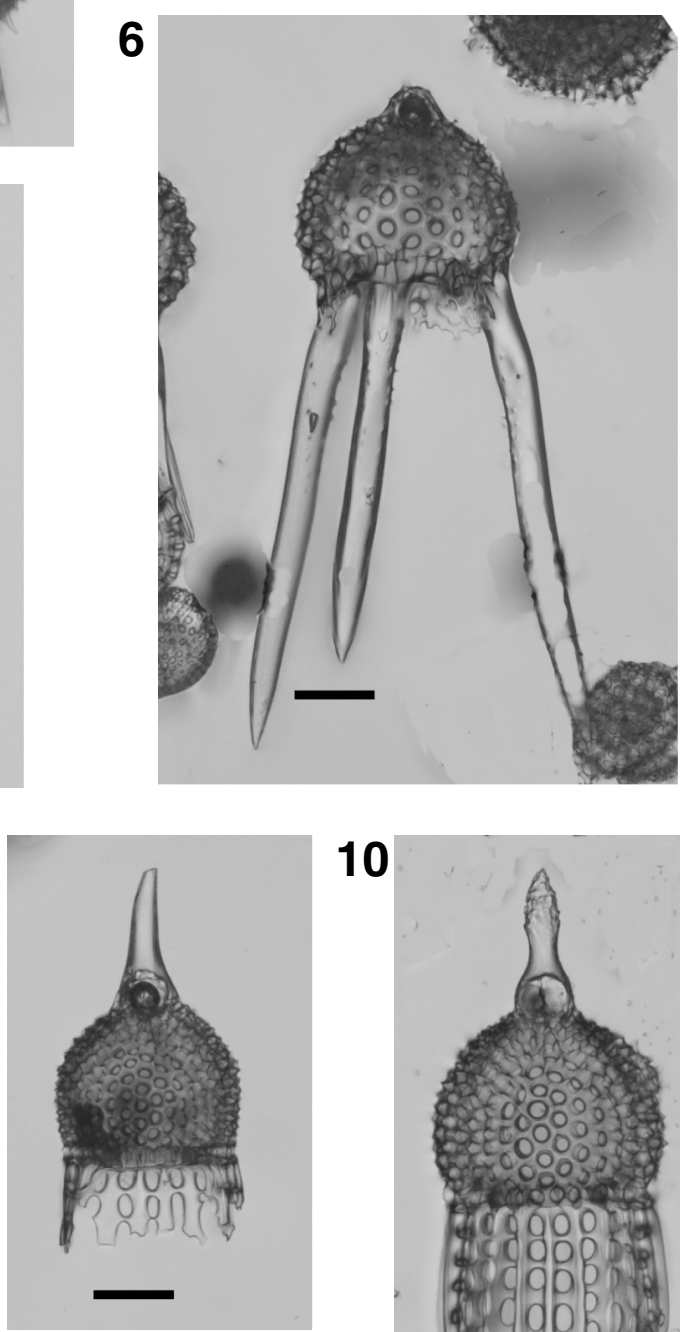

12

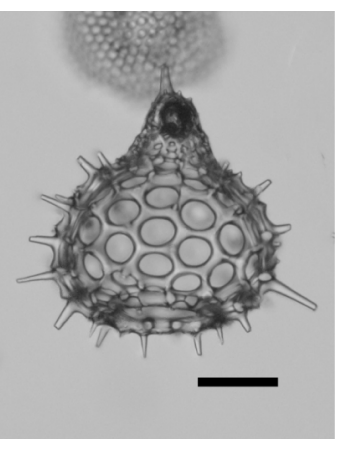

13

10

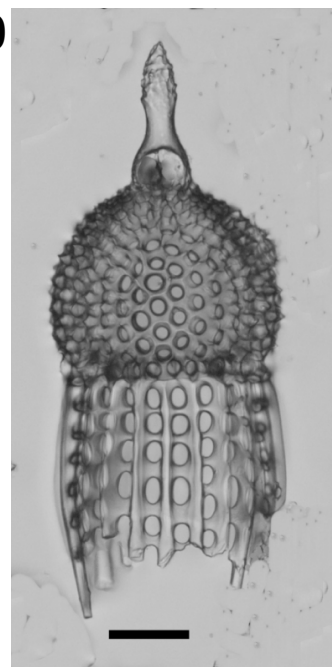

4

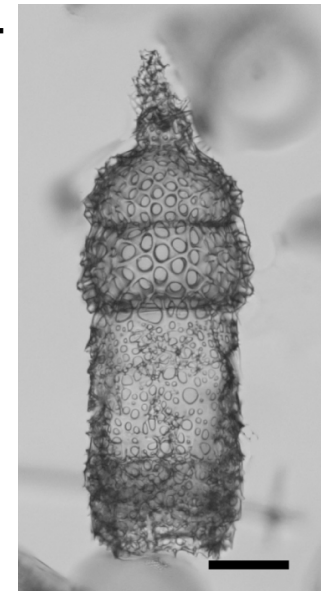

7

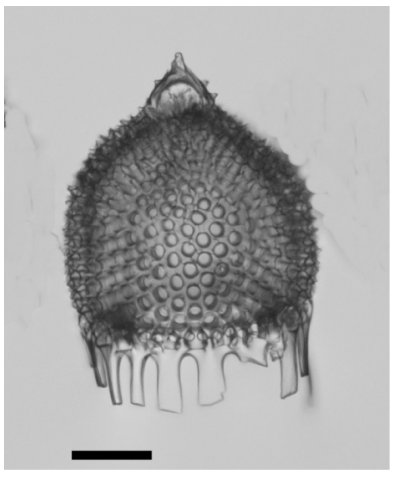

11

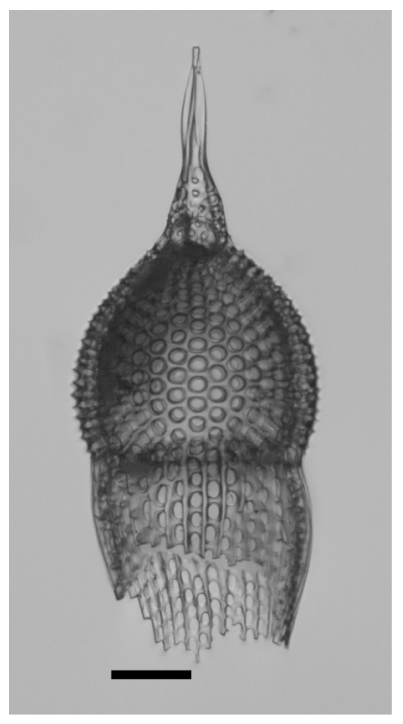

14 
Plate P2. Cryptocarpium through Dorcadospyris. All scale bars $=50 \mathrm{~mm}$. Sample depths are corrected and adjusted corresponding to depths (revised meters composite depth [rmcd]) in ODP Site 1218 (from Westerhold et al., 2012). (Plate shown on next page.)

1. Cryptocarpium azyx (Sanfilippo and Riedel) (Sample 320-U1333A-14H-4, 40-41 cm; 254.79 rmcd).

2. Cryptocarpium ornatum (Ehrenberg) (Sample 199-1218B-25X-2, 100-101 cm; $258.60 \mathrm{rmcd}$ ).

3. Cryptocarpium ornatum (Ehrenberg) (Sample 320-U1333C-14X-7, 30-38 cm; $246.33 \mathrm{rmcd}$ ).

4. Cryptocarpium ornatum (Ehrenberg) (Sample 320-U1334B-27X-5, 130-131 cm; $248.70 \mathrm{rmcd}$ ).

5. Dictyoprora armadillo (Ehrenberg) group (Sample 199-1218B-25X-2, 100-101 cm; $253.21 \mathrm{rmcd}$ ).

6. Dictyoprora mongolfieri (Ehrenberg) (Sample 320-U1333B-13H-7, 20-21 cm; $249.16 \mathrm{rmcd}$ ).

7. Dorcadospyris anastasis Sanfilippo (Sample 320-U1333A-15X-1, 40-41 cm; 268.19 rmcd).

8. Dorcadospyris anastasis Sanfilippo (Sample 320-U1333A-15X-4, 96-98 cm; $265.90 \mathrm{rmcd}$ ).

9. Dorcadospyris copelata Sanfilippo (Sample 320-U1333C-14X-7, 30-38 cm; $246.33 \mathrm{rmcd}$ ).

10. Dorcadospyris cf. D. ateuchus (Ehrenberg) (Sample 320-U1334B-26X-1, 80-81 cm; 235.07 rmcd).

11. Dorcadospyris cf. D. ateuchus (Ehrenberg) (Sample 320-U1334B-26X-1, 80-81 cm; 235.07 rmcd).

12. Dorcadospyris copelata Sanfilippo (Sample 320-U1333A-14X-6, 20-21cm; $259.03 \mathrm{rmcd}$ ). 
Plate P2 (continued). (Caption shown on previous page.)
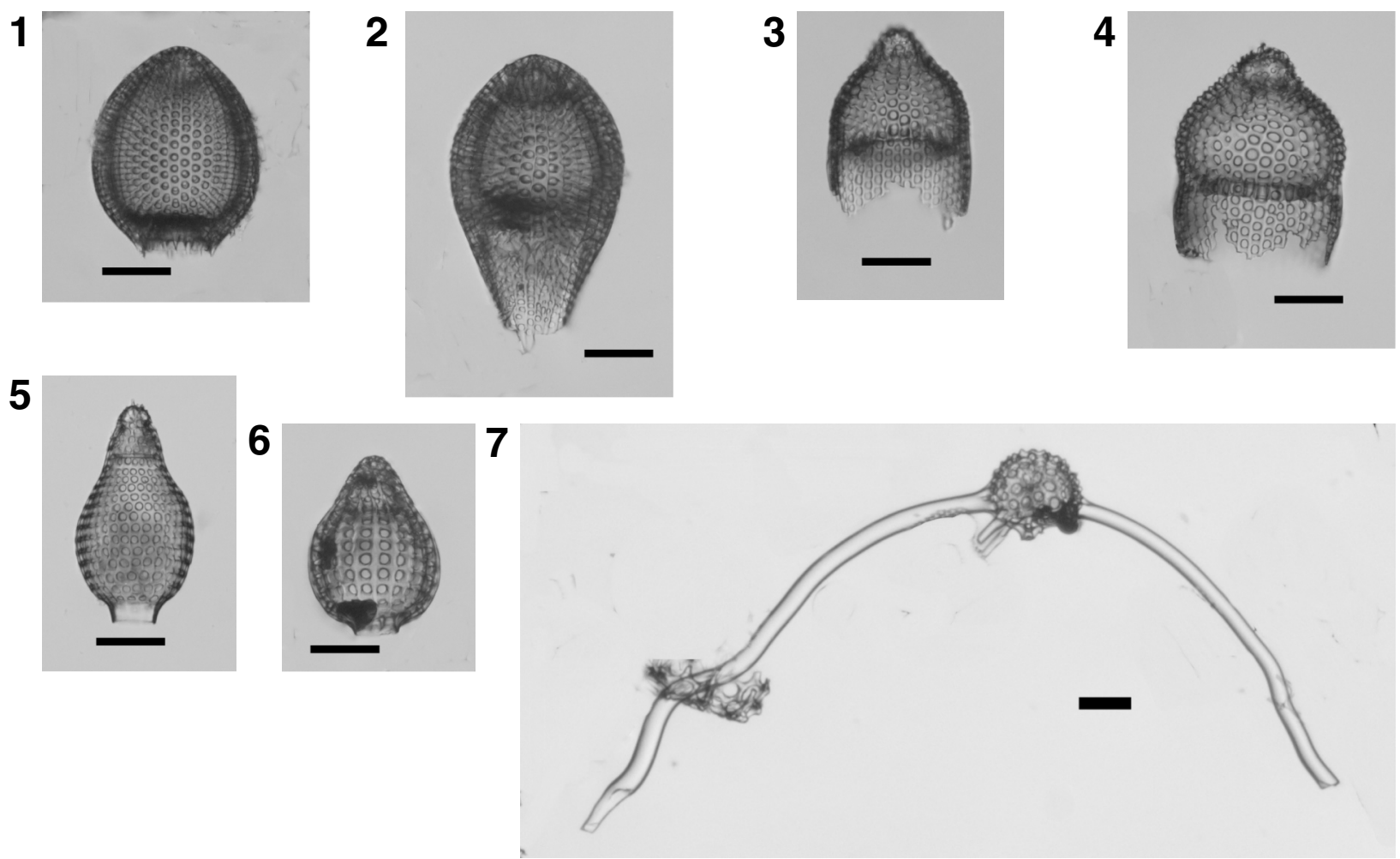

8
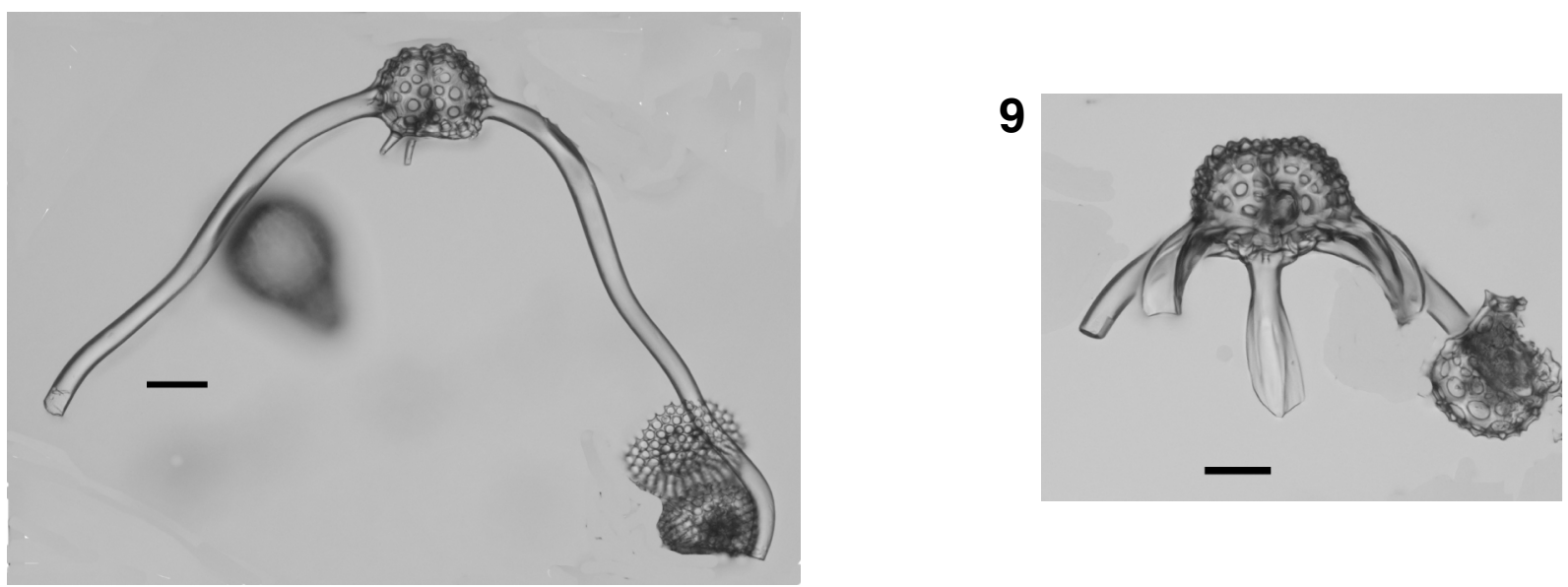

10

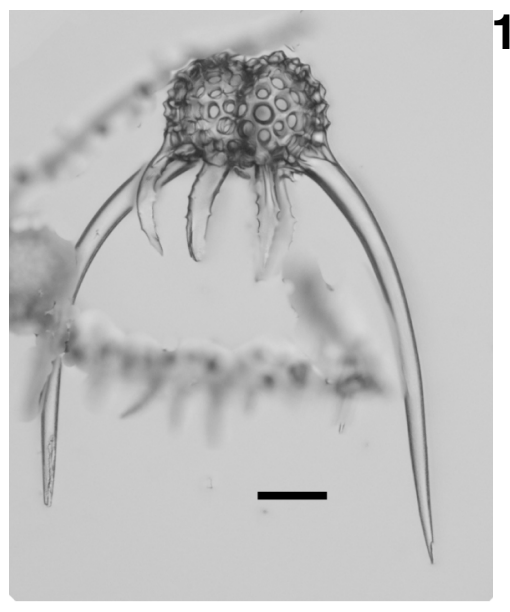

11

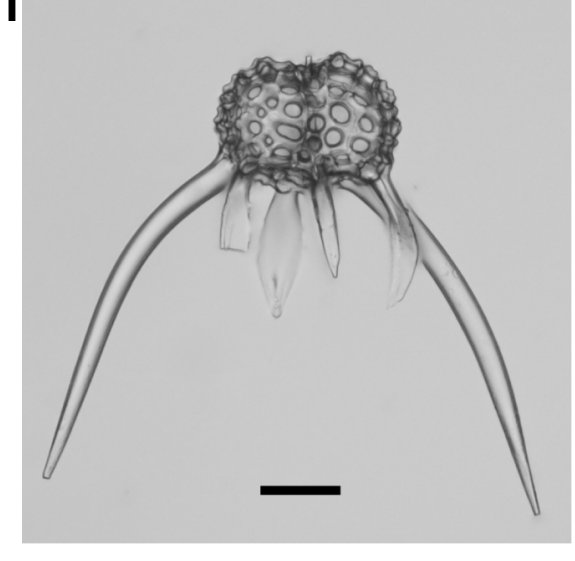

12

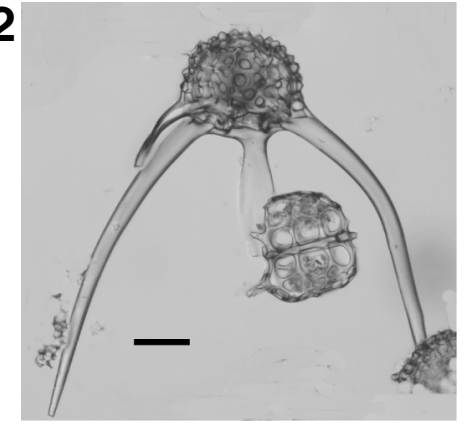


Plate P3. Dorcadospyris. All scale bars $=50 \mathrm{~mm}$. Sample depths are corrected and adjusted corresponding to depths (revised meters composite depth [rmcd]) in ODP Site 1218 (from Westerhold et al., 2012). (Plate shown on next page.)

1. Dorcadospyris mahurangi (?) O'Connor (Sample 320-U1333C-10H-2, 150-151 cm; $196.38 \mathrm{rmcd}$ ).

2. Dorcadospyris mahurangi (?) O'Connor (Sample 199-1218B-20X-2, 99-100 cm; 198.29 rmcd).

3. Dorcadospyris ombros Sanfilippo (Sample 199-1218B-26X-3, 50-51 cm; $258.37 \mathrm{rmcd}$ ).

4. Dorcadospyris ombros Sanfilippo (Sample 199-1218B-24X-6, 50-51 cm; $247.56 \mathrm{rmcd}$ ).

5. Dorcadospyris pseudopapilio Moore (Sample 320-U1333C-13H-5, 150-151 cm; $227.91 \mathrm{rmcd}$ ).

6. Dorcadospyris cf. D. ombros Sanfilippo (Sample 320-U1333C-10H-2, 150-151 cm; 195.26 rmcd).

7. Dorcadospyris cf. D. ombros Sanfilippo (Sample 320-1333C-10H-2, 60-61 cm; 249.60 rmcd).

8. Dorcadospyris aff. D. pseudopapilio Moore (Sample 320-U1334A-26X-4, 80-81 cm; 232.75 rmcd).

9. Dorcadospyris aff. D. pseudopapilio Moore (Sample 320-U1334A-26X-3, 50-51 cm; 231.57 rmcd). 
Plate P3 (continued). (Caption shown on previous page.)

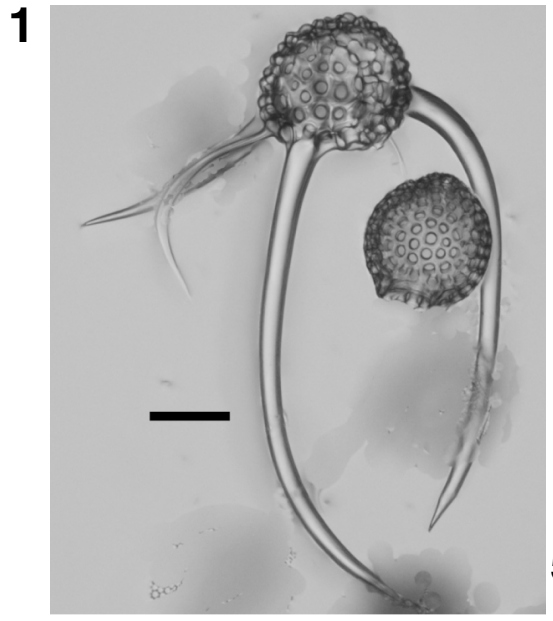

\section{4}

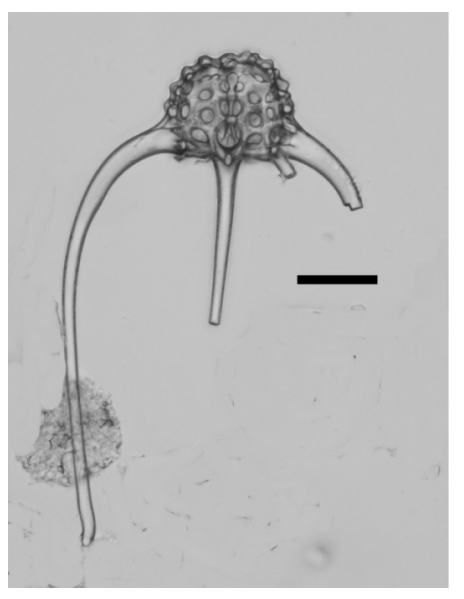

\section{8}

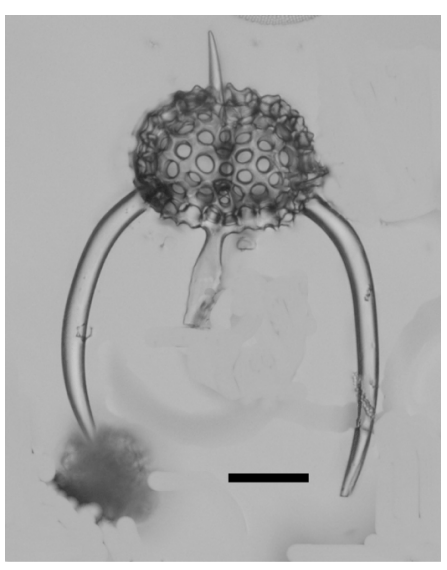

2

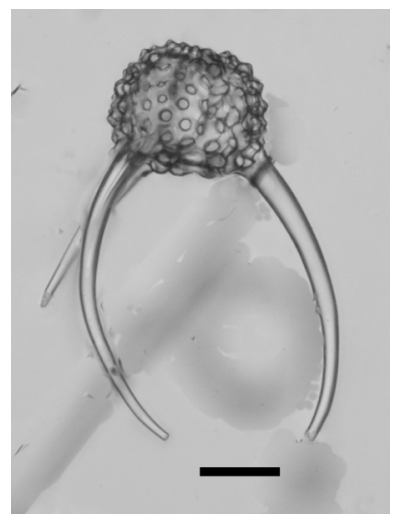

5

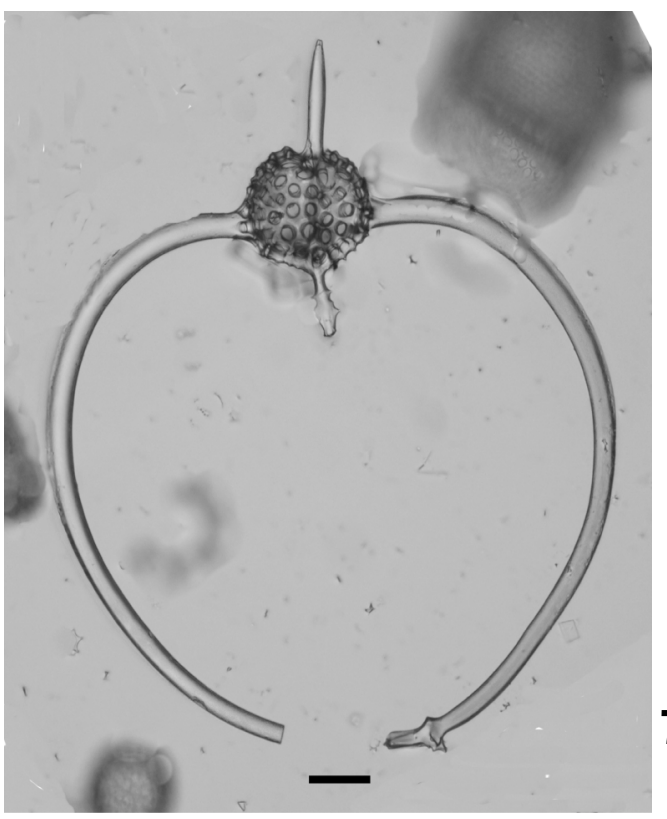

9

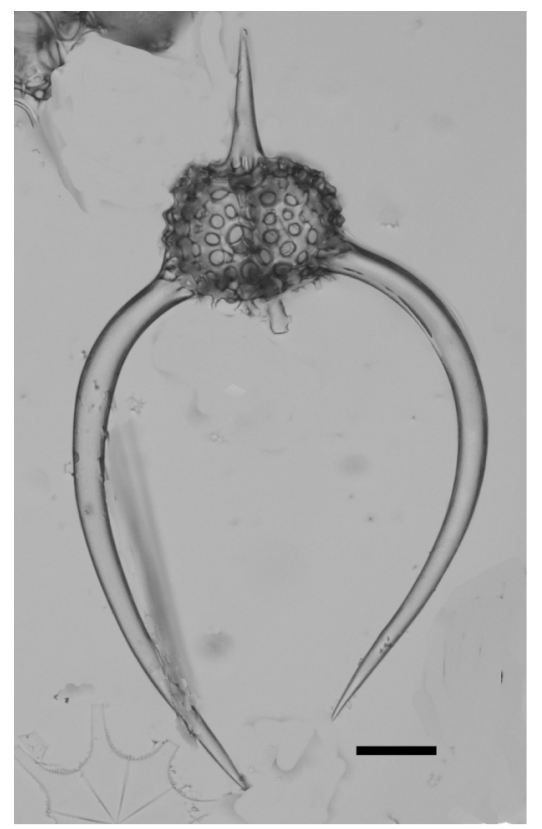

3

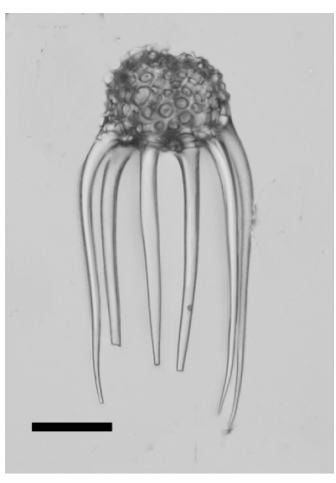

6

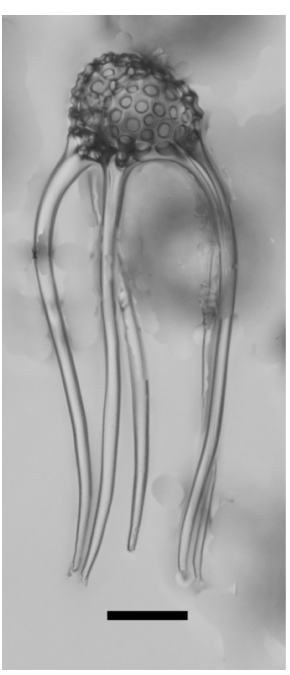

7

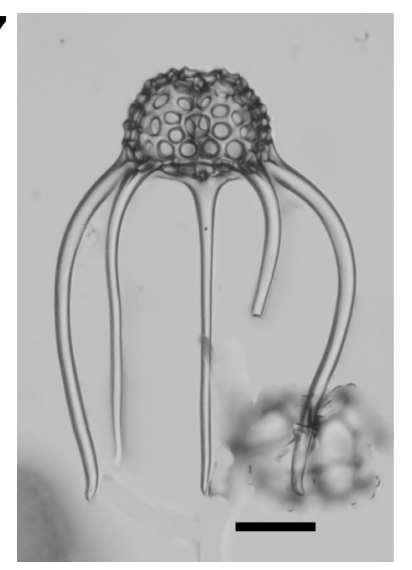


Plate P4. Dorcadospyris. All scale bars $=50 \mathrm{~mm}$. Sample depths are corrected and adjusted corresponding to depths (revised meters composite depth [rmcd]) in ODP Site 1218 (from Westerhold et al., 2012). (Plate shown on next page.)

1. Dorcadospyris quadripes Moore (Sample 320-U1333B-12H-4, 0-1 cm; $228.98 \mathrm{rmcd}$ ).

2. Dorcadospyris quadripes Moore (Sample 320-U1333C-12H-2, 100-101 cm; $218.35 \mathrm{rmcd}$ ).

3. Dorcadospyris quadripes Moore (Sample 320-U1333C-13H-2, 50-51 cm; $221.90 \mathrm{rmcd}$ ).

4. Dorcadospyris cf. D. spinosa Moore (Sample 320-U1333C-15H-2, 30-31 cm; $249.60 \mathrm{rmcd}$ ).

5. Dorcadospyris cf. D. spinosa Moore (Sample 199-1218B-24X-6, 104-106 cm; $248.10 \mathrm{rmcd}$ ).

6. Dorcadospyris aff. D. spinosa Moore (Sample 320-U1333C-13H-3, 101-103 cm; $224.10 \mathrm{rmcd}$ ).

7. Dorcadospyris aff. D. spinosa Moore (Sample 320-U1333C-13H-2, 50-51 cm; $224.90 \mathrm{rmcd}$ ).

8. Dorcadospyris spinosa Moore (Sample 320-U1333C-12H-4, 100-101 cm; $219.74 \mathrm{rmcd}$ ).

9. Dorcadospyris spinosa Moore (Sample 320-U1333C-11H-5,100-101 cm; $211.80 \mathrm{rmcd}$ ). 
Plate P4 (continued). (Caption shown on previous page.)

1

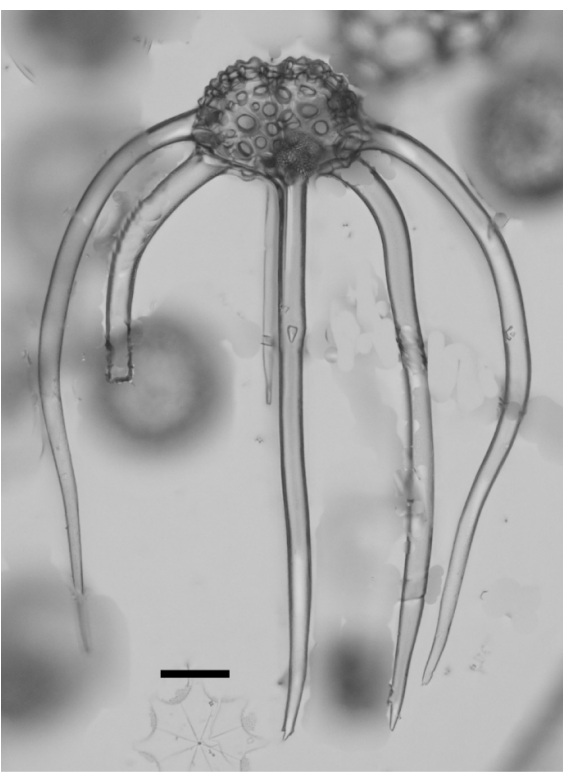

2

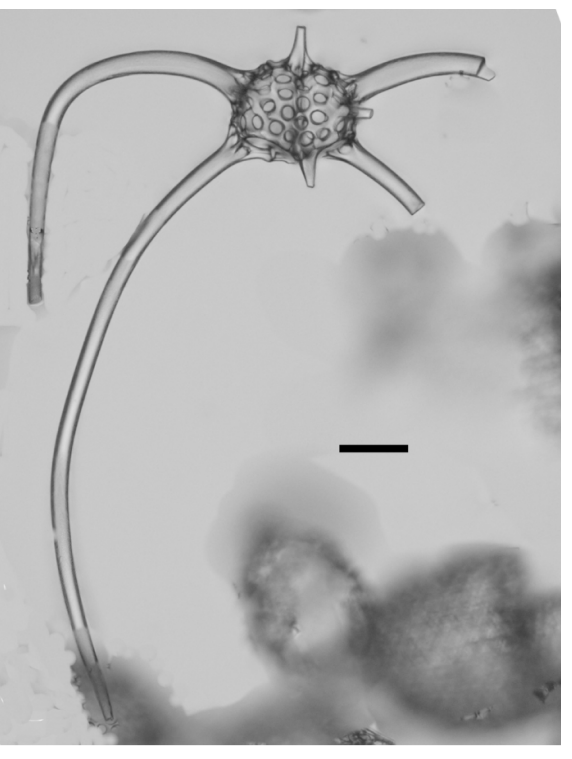

4

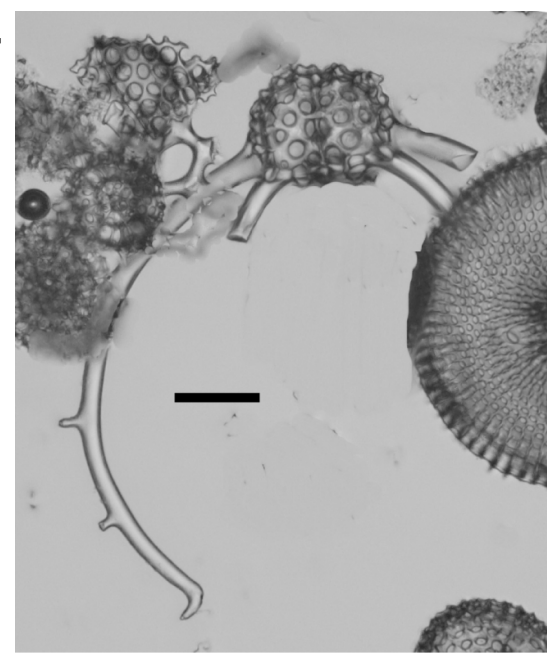

5

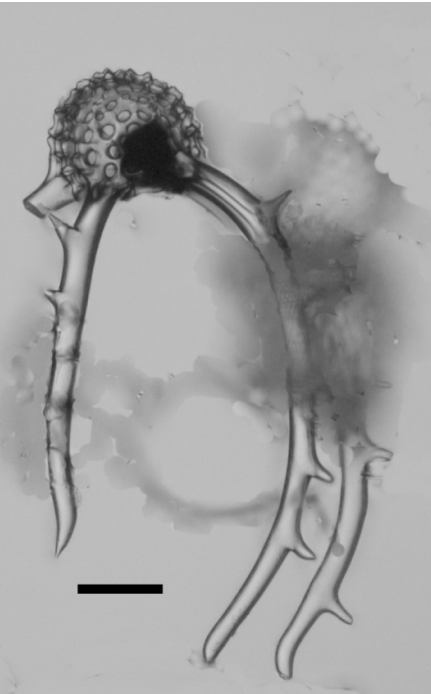

3

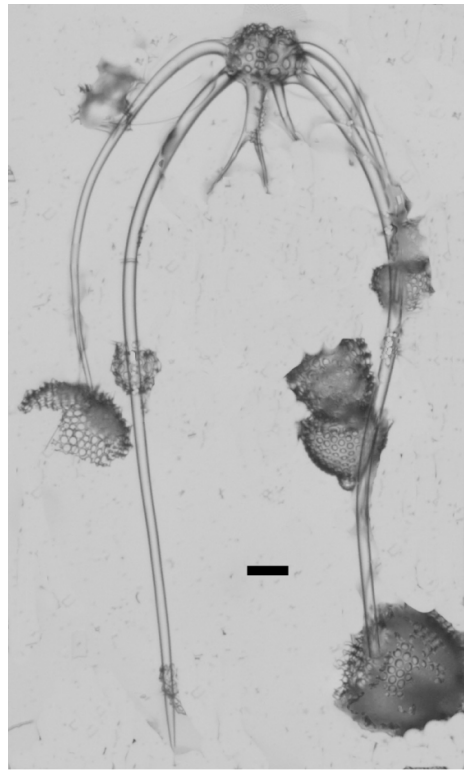

6

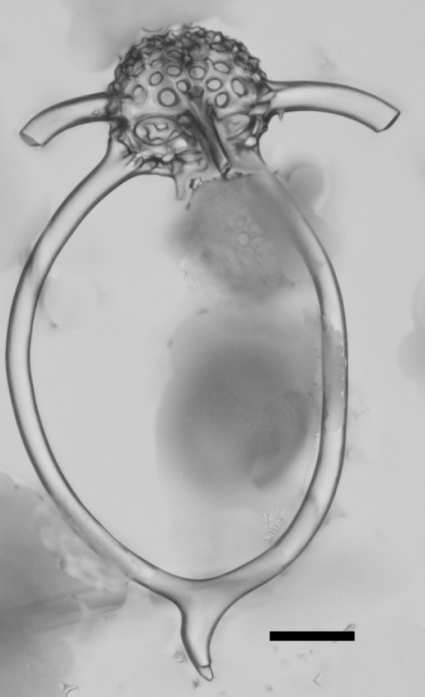

\section{7}

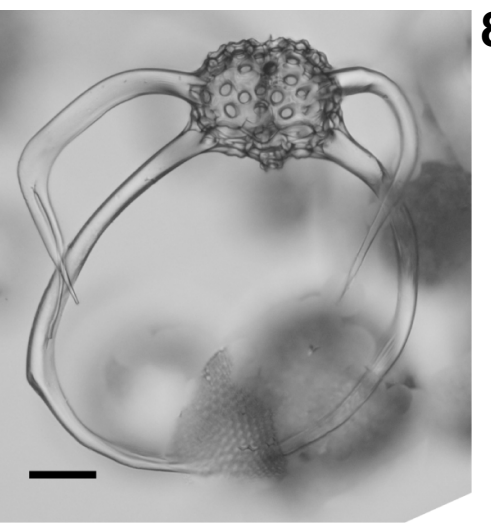

8

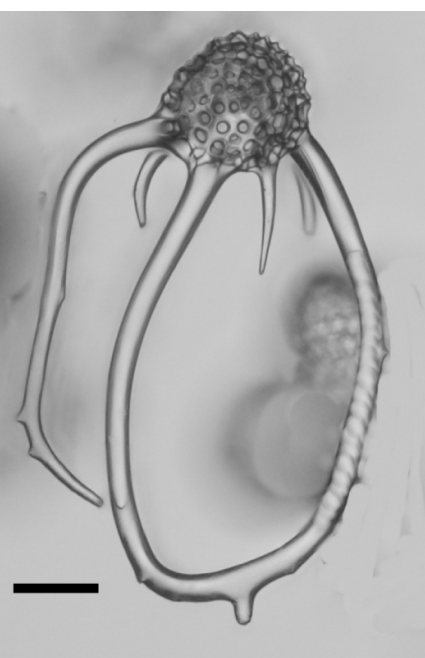

9

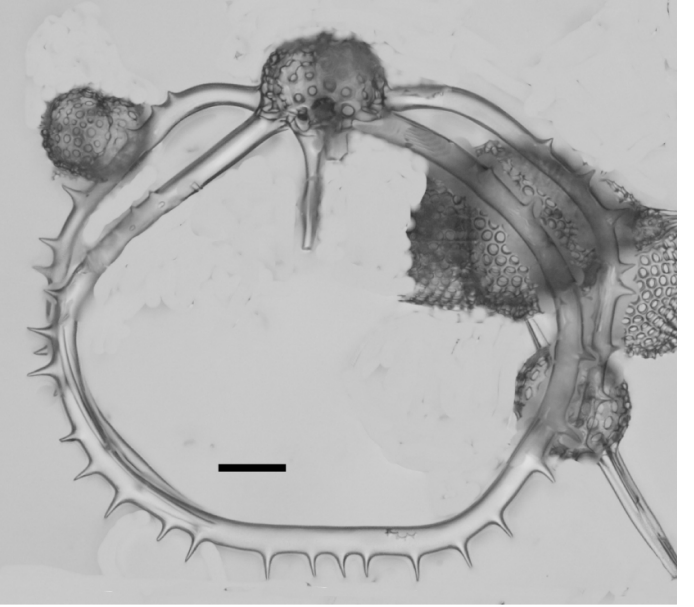


Plate P5. Eucyrtidium through Lithocyclia. All scale bars $=50 \mathrm{~mm}$. Sample depths are corrected and adjusted corresponding to depths (revised meters composite depth [rmcd]) in ODP Site 1218 (from Westerhold et al., 2012). (Plate shown on next page.)

1. Eusyringium fistuligerum (Ehrenberg) (Sample 320-U1333A-15X-3, 80-81 cm; $264.10 \mathrm{rmcd}$ ).

2. Eucyrtidium plesiodiaphanes Sanfilippo (Sample 320-U1333C-10H-2, 105-106 cm; 195.82 rmcd).

3. Eucyrtidium plesiodiaphanes Sanfilippo (Sample 320-U1333C-10H-2, 150-151 cm; $196.38 \mathrm{rmcd}$ ).

4. Lithochytris vespertilio Ehrenberg; reworked specimen (Sample 320-U1333A-15X-1, 60-61 cm; 268.29 rmcd).

5. Lithocyclia angusta (Riedel) (Sample 320-U1334B-26X-4, 40-41 cm; $238.52 \mathrm{rmcd}$ ).

6. Lithocyclia aristotelis (Ehrenberg) group; two specimens, each with three arms (Sample 199-1218B-26X-3, 50$51 \mathrm{~cm} ; 258.37 \mathrm{rmcd})$.

7. Lithocyclia angusta (Riedel) (Sample 320-U1334A-26X-3, 81-82 cm; 231.77 rmcd).

8. Lithocyclia angusta (Riedel) (Sample 320-U1333C-11X-5, 148-150 cm; $212.58 \mathrm{rmcd}$ ).

9. Lithocyclia aristotelis (Ehrenberg) group; four-arm variety (Sample 199-1218B-26X-3, 50-51 cm; $258.37 \mathrm{rmcd}$ ).

10. Lithocyclia crux Moore (Sample 320-U1333C-13H-3, 101-103 cm; $224.10 \mathrm{rmcd}$ ).

11. Lithocyclia cf. L. crux Moore, var. A (Sample 320-U1334B-26X-1, 110-111 cm; $235.15 \mathrm{rmcd}$ ).

12. Lithocyclia cf. L. crux Moore, var B (Sample 320-U1333C-11H-5, 100-101 cm; $211.80 \mathrm{rmcd}$ ).

13. Lithocyclia cf. L. crux Moore, var. B (Sample 320-U1334A-26X-4, 104-106 cm; $232.91 \mathrm{rmcd}$ ).

14. Lithocyclia cf. L. crux Moore, var. A (Sample 320-U1333C-13H-3, 148-149 cm; $224.65 \mathrm{rmcd}$ ). 
Plate P5 (continued). (Caption shown on previous page.)
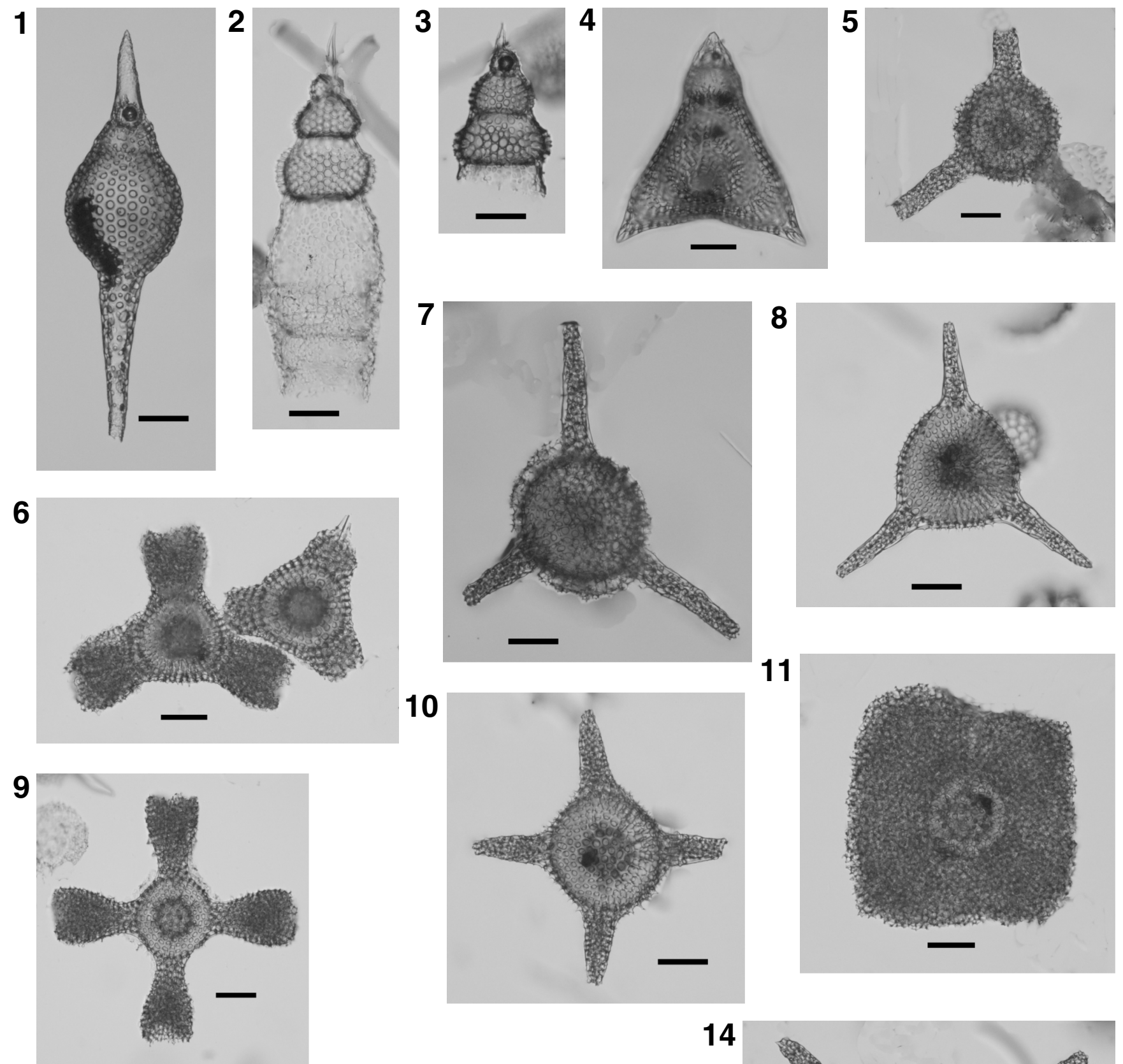

\section{1}

12

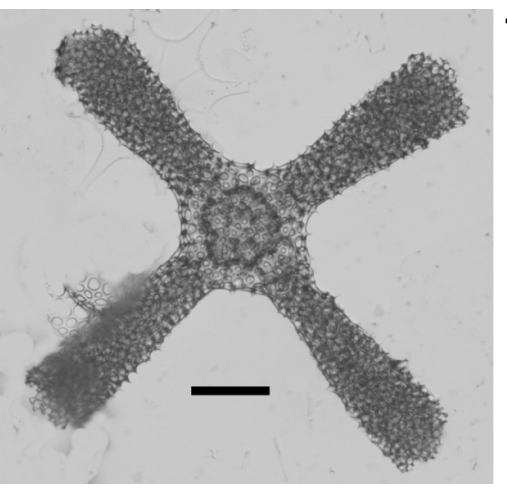

13

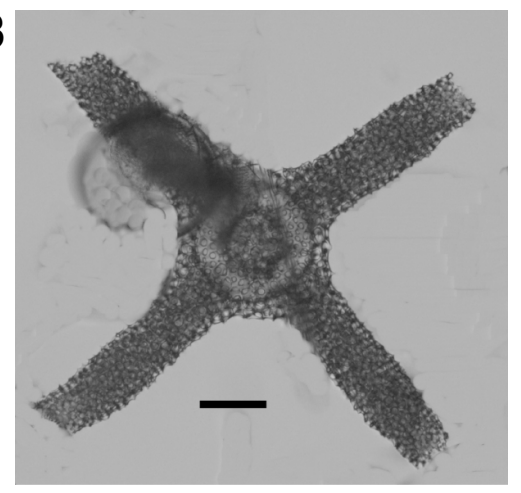

14

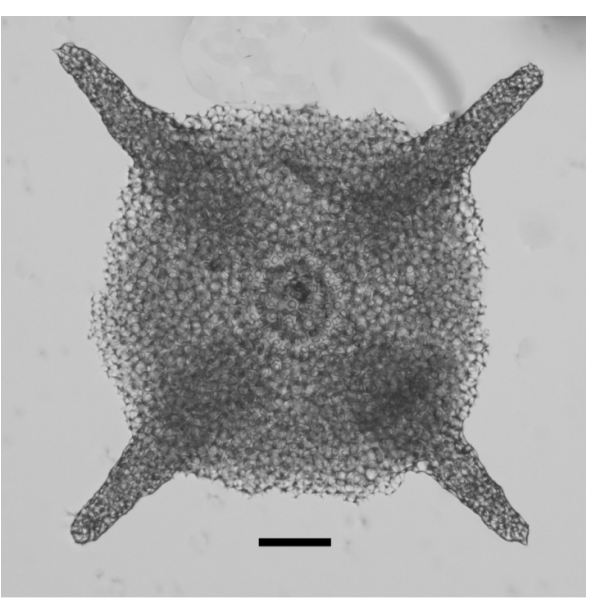


Plate P6. Lithocyclia through Lophocyrtis. All scale bars $=50 \mathrm{~mm}$. Sample depths are corrected and adjusted corresponding to depths (revised meters composite depth [rmcd]) in ODP Site 1218 (from Westerhold et al., 2012). (Plate shown on next page.)

1. Lithocyclia cf. L. crux Moore, var. C (Sample 320-U1333C-10H-2, 150-151 cm; $196.38 \mathrm{rmcd}$ ).

2. Lithocyclia ocellus Ehrenberg group (Sample 320-U1333A-15X-1, 40-41 cm; $262.18 \mathrm{rmcd}$ ).

3. Lophocyrtis (Cyclampterium) hadra Riedel and Sanfilippo (Sample 320-U1334C-28X-4, 100-101 cm; 245.56 rmcd).

4. Lophocyrtis (Cyclampterium) hadra Riedel and Sanfilippo (Sample 320-U1334C-28X-4, 40-41 cm; 245.07 rmcd).

5. Lophocyrtis (Lophocyrtis) jacchia (Ehrenberg) (Sample 320-U1334B-27X-4, 40-41 cm; $247.23 \mathrm{rmcd}$ ).

6. Lophocyrtis (Cyclampterium) milowi (Riedel and Sanfilippo) (Sample 320-U1334B-26X-1, 110-111 cm; 235.15 rmcd).

7. Lophocyrtis (Cyclampterium) milowi (Riedel and Sanfilippo) (Sample 320-U1333C-13H-3, 101-103 cm; 224.10 rmcd).

8. Lophocyrtis (Sciadiopeplus) oberhaensliae Sanfilippo (320-U1333B-12H-4, 100-101 cm; 229.95 rmcd).

9. Lophocyrtis (Sciadiopeplus) oberhaensliae Sanfilippo (Sample 320-U1333B-12H-4, 0-1 cm; $228.98 \mathrm{rmcd}$ ). 
Plate P6 (continued). (Caption shown on previous page.)

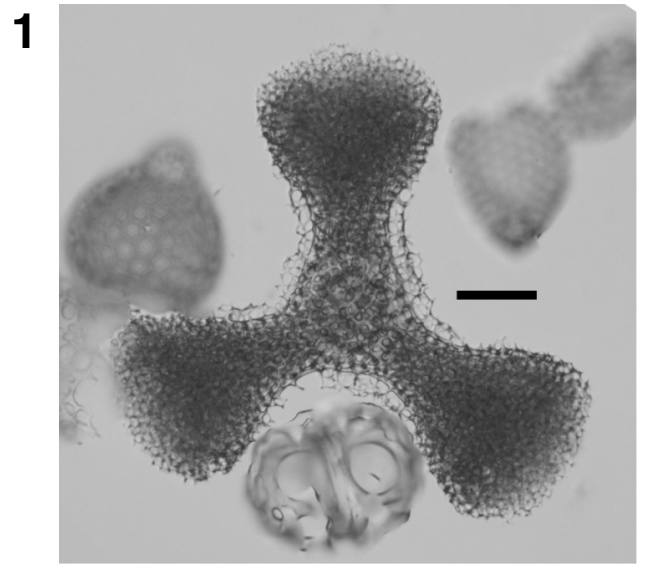

4

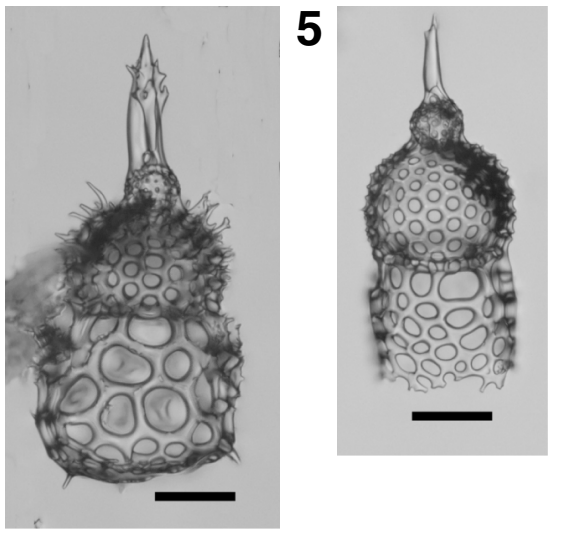

2

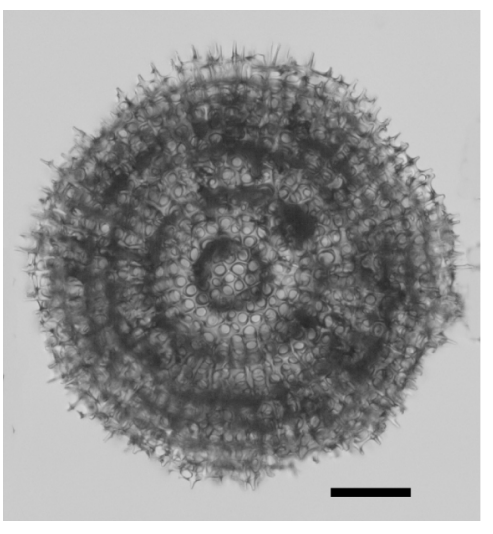

6

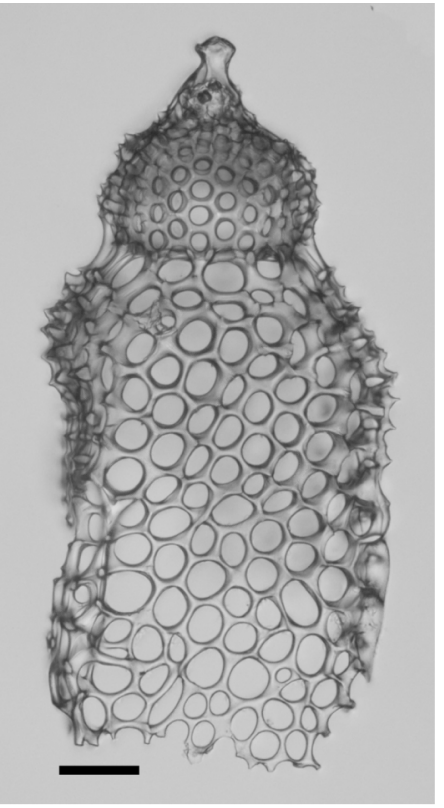

\section{7}

3
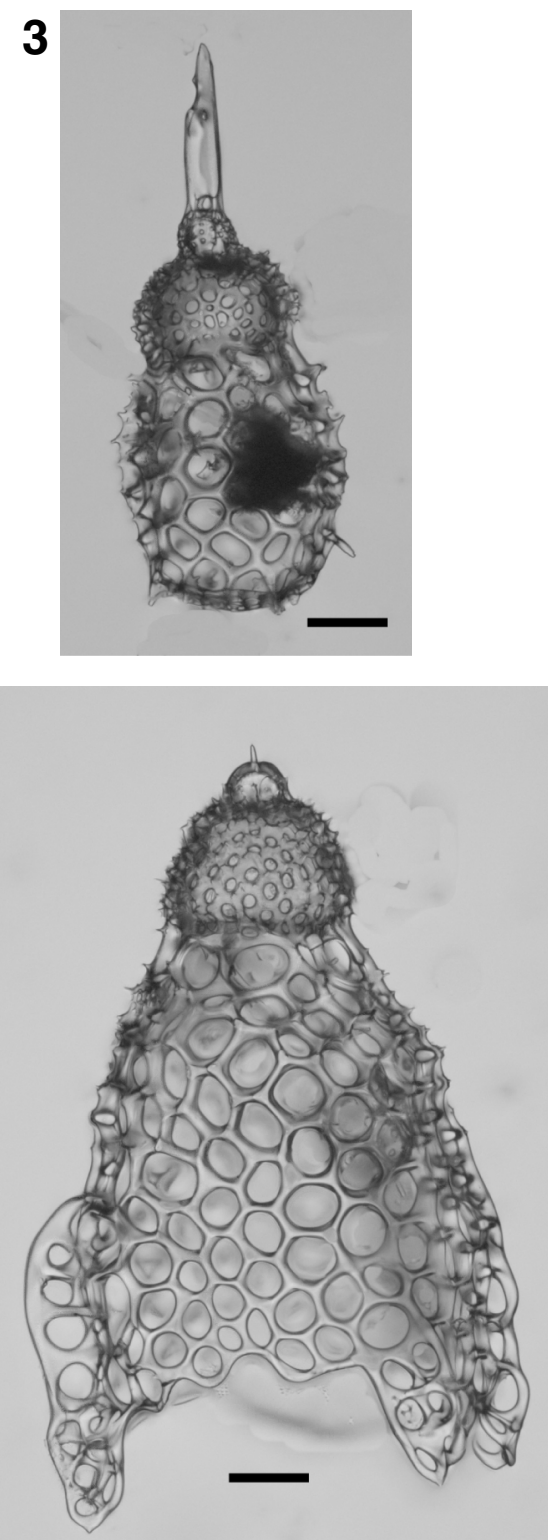

9

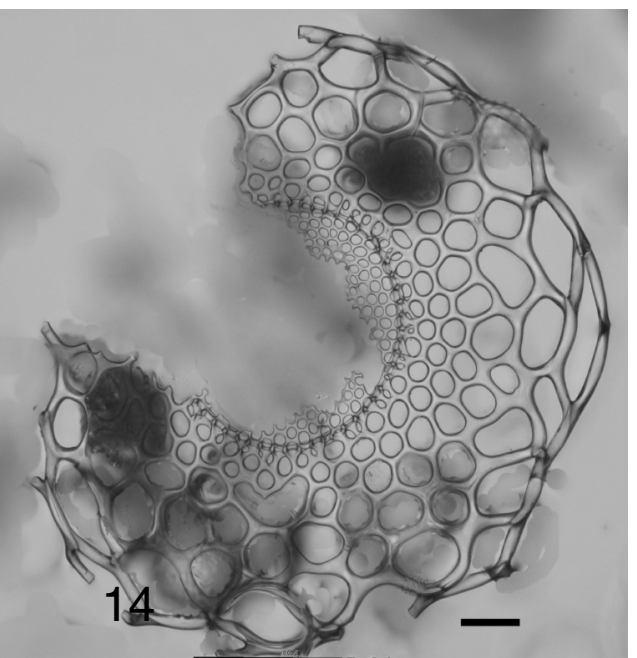


Plate P7. Lychnocanoma through Theocotylissa. All scale bars $=50 \mathrm{~mm}$. Sample depths are corrected and adjusted corresponding to depths (revised meters composite depth [rmcd]) in ODP Site 1218 (from Westerhold et al., 2012). (Plate shown on next page.)

1. Lychnocanoma amphitrite Foreman (Sample 320-U1333C-15X-4, 10-11 cm; $251.71 \mathrm{rmcd}$ ).

2. Lychnocanoma amphitrite Foreman (Sample 320-U1333B-13H-5, 140-141 cm; $247.45 \mathrm{rmcd}$ ).

3. Lychnocanoma babylonis (Clark and Campbell) group (Sample 199-1218B-26X-3, 50-51 cm; $258.37 \mathrm{rmcd}$ ).

4. Lychnocanoma turgidum (Ehrenberg) (Sample 320-U1333A-14X-7, 30-31cm; $259.50 \mathrm{rmcd}$ ).

5. Podocyrtis (Lampterium) trachodes Riedel and Sanfilippo, reworked specimen (Sample 320-U1333A-15X-3, 80$81 \mathrm{~cm} ; 264.63 \mathrm{rmcd})$.

6. Podocyrtis (Podocyrtis) papalis Ehrenberg (Sample 320-U1333A-15X-1, 60-61 cm; 268.29 rmcd).

7. Podocyrtis (Podocyrtopsis) apeza Sanfilippo and Riedel (Sample 320-U1333A-15X-2, 143-144 cm; 264.10 rmcd).

8. Podocyrtis (Lampterium) chalara Riedel and Sanfilippo (Sample 320-U1333A-14X-4, 120-121 cm; 255.72 rmcd).

9. Podocyrtis (Lampterium) goetheana (Haeckel) (Sample 320-U1333A-15X-2, 143-144 cm; $264.10 \mathrm{rmcd}$ ).

10. Spongatractus pachystylus (Ehrenberg) (Sample 320-U1333A-15X-3, 100-101 cm; $264.73 \mathrm{rmcd}$ ).

11. Theocorys puriri O'Connor (Sample 320-U1333C-13H-5, 150-151 cm; $227.91 \mathrm{rmcd}$ ).

12. Theocorys puriri O'Connor (Sample 320-U1333C-13H-3, 101-102 cm; $224.10 \mathrm{rmcd}$ ).

13. Rhopalocanium ornatum Ehrenberg, reworked specimen (Sample 199-1218B-25X-2, 100-101 cm; 253.21 rmcd).

14. Sethochytris triconiscus Haeckel, reworked specimen (Sample 320-U1333A-14X-4, 120-121 cm; 255.72 rmcd).

15. Pteropilium sp. aff. Pterocanium contiguum (Ehrenberg) (Sample 320-U1334A-26X-CC; 236.37 rmcd).

16. Theocotylissa ficus (Ehrenberg) (Sample 320-U1333A-15X-3, 80-81 cm; $264.63 \mathrm{rmcd}$ ).

17. Theocorys spongoconus Kling (Sample 320-U1333C-11H-5, 148-150 cm; 212.58 rmcd).

18. Theocorys spongoconus Kling (Sample 320-U1333C-11H-5, 100-101 cm; 211.80 rmcd). 
Plate P7 (continued). (Caption shown on previous page.)
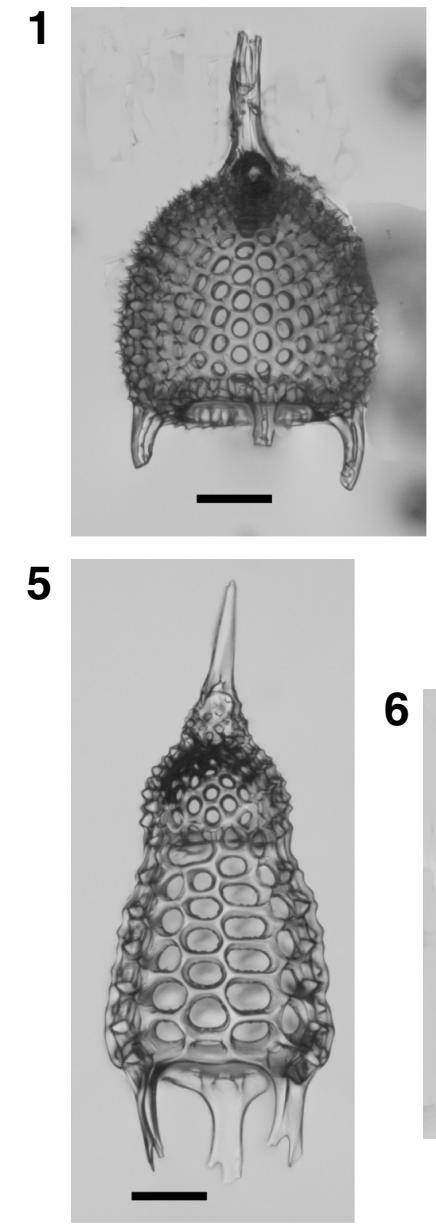

10

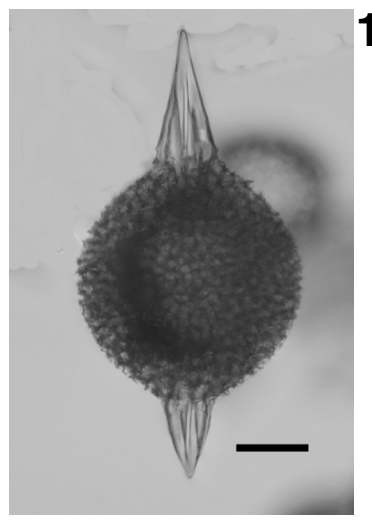

17
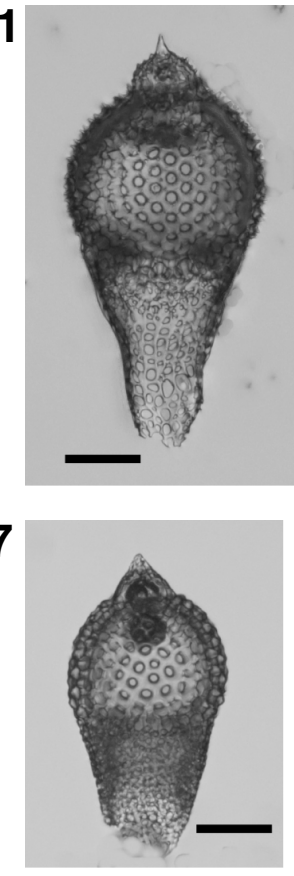

2

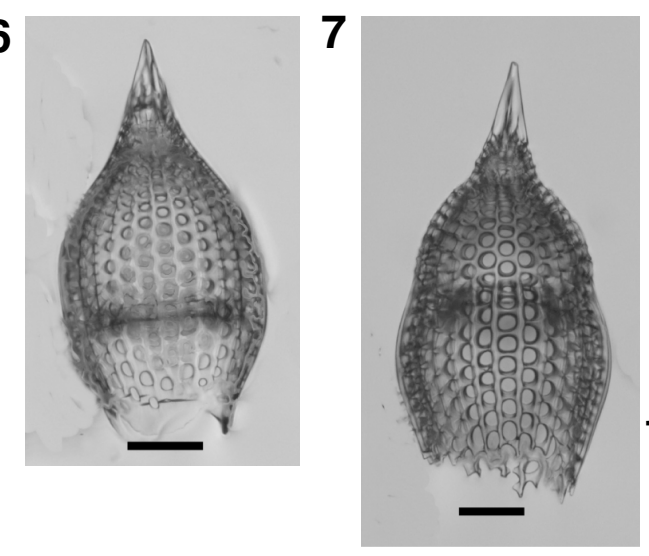

12

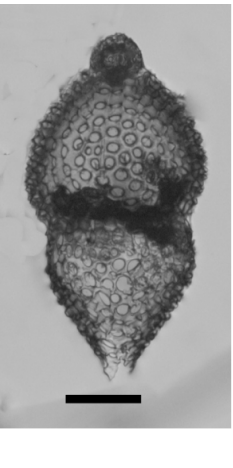

18

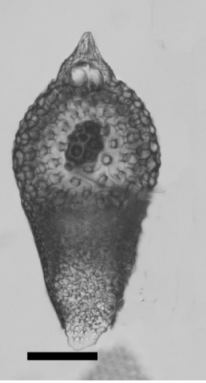

3

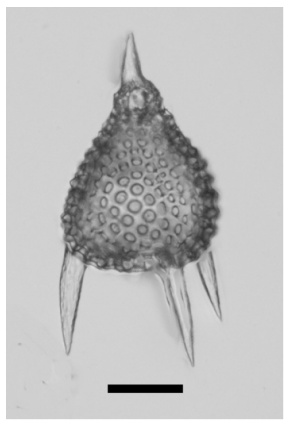

8

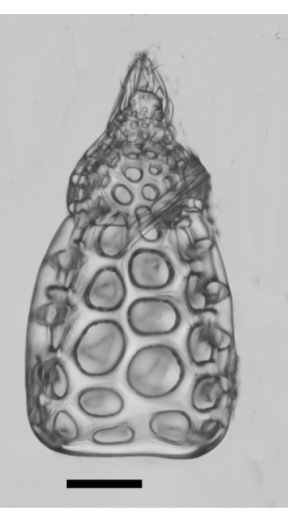

13
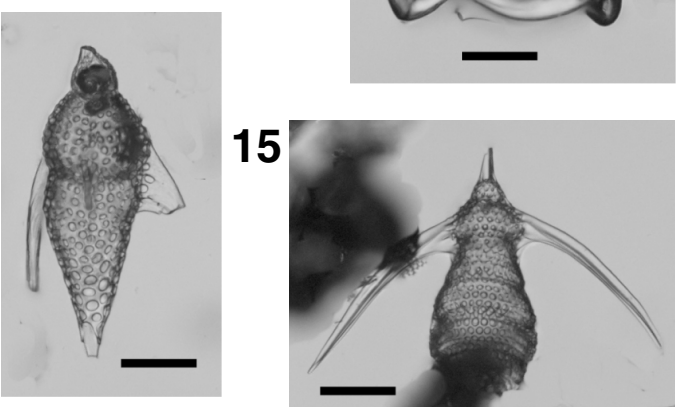

14

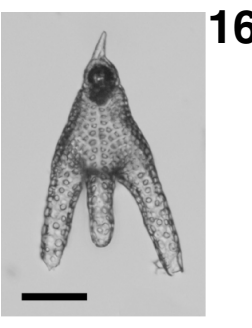

4

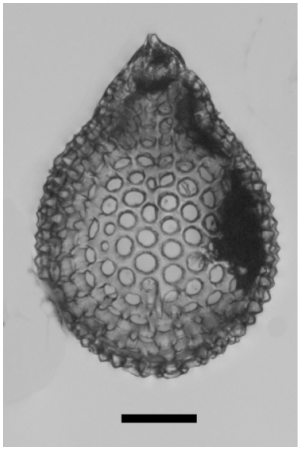

9

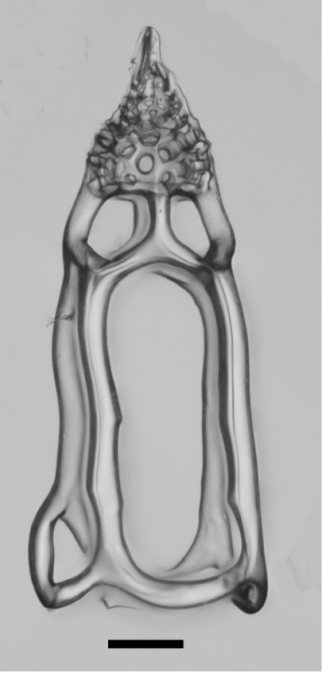

16

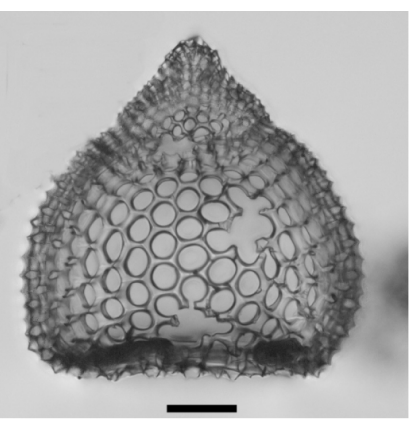


Plate P8. Theocyrtis through Thyrsocyrtis. All scale bars $=50 \mathrm{~mm}$. Sample depths are corrected and adjusted corresponding to depths (revised meters composite depth [rmcd]) in ODP Site 1218 (from Westerhold et al., 2012). (Plate shown on next page.)

1. Theocyrtis careotuberosa Nigrini and Sanfilippo (Sample 320-U1334B-26X-4, 130-131 cm; $239.38 \mathrm{rmcd}$ ).

2. Thyrsocyrtis aff. T. careotuberosa Nigrini and Sanfilippo (Sample 320-U1333C-11H-5, 148-150 cm; 212.58 rmcd).

3. Thyrsocyrtis aff. T. careotuberosa Nigrini and Sanfilippo (Sample 320-U1333C-11H-5, 148-150 cm; 212.58 rmcd).

4. Theocyrtis perpumila Sanfilippo (Sample 199-1218B-26X-3, 50-51 cm; $258.37 \mathrm{rmcd}$ ).

5. Theocyrtis tuberosa Riedel, emend. Sanfilippo et al. (Sample 320-U1334A-26X-3, 109-110 cm; 231.96 rmcd).

6. Theocyrtis tuberosa Riedel, emend. Sanfilippo et al. (Sample 320-U1334B-12H-4, 100-101 cm; 229.95 rmcd).

7. Thyrsocyrtis (Pentalacorys) krooni Sanfilippo and Blome (Sample 320-U1333A-15X-1, 80-81 cm; 262.39 rmcd).

8. Thyrsocyrtis (Pentalacorys) krooni Sanfilippo and Blome (Sample 320-U1333A-15X-1, 80-81 cm; 262.39 rmcd).

9. Thyrsocyrtis (Pentalacorys) lochites Sanfilippo and Riedel (Sample 320-U1333A-14H-5, 140-141 cm; 255.85 rmcd).

10. Thyrsocyrtis (Pentalacorys) lochites Sanfilippo and Riedel (Sample 320-U1333C-15H-4, 70-71 cm; 253.21 rmcd).

11. Thyrsocyrtis aff. T. (Pentalacorys) lochites Sanfilippo and Riedel (Sample 320-U1333A-14H-5, 130-131 cm; $257.39 \mathrm{rmcd})$.

12. Thyrsocyrtis aff. T. (Pentalacorys) lochites Sanfilippo and Riedel (Sample 320-U1333A-14H-5, 30-31 cm; $256.16 \mathrm{rmcd})$.

13. Thyrsocyrtis (Pentalacorys) orthotenes Sanfilippo (Sample 320-U1333A-14H-5, 150-151 cm; $257.60 \mathrm{rmcd}$ ).

14. Thyrsocyrtis (Pentalacorys) tetracantha (Ehrenberg) (Sample 320-U1333A-14X-4, 140-141 cm; $255.85 \mathrm{rmcd}$ ).

15. Thyrsocyrtis (Pentalacorys) tetracantha (Ehrenberg) (Sample 320-U1333A-14H-4, 120-121 cm; $255.72 \mathrm{rmcd}$ ). 
Plate P8 (continued). (Caption shown on previous page.)

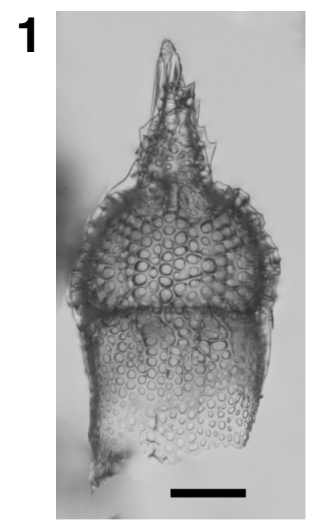

2

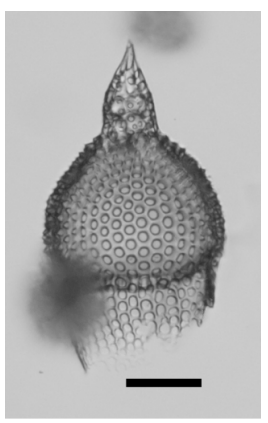

3

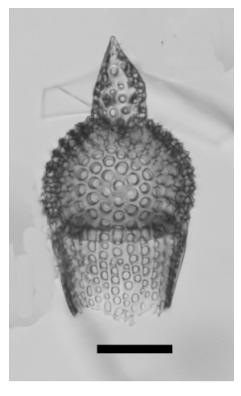

4
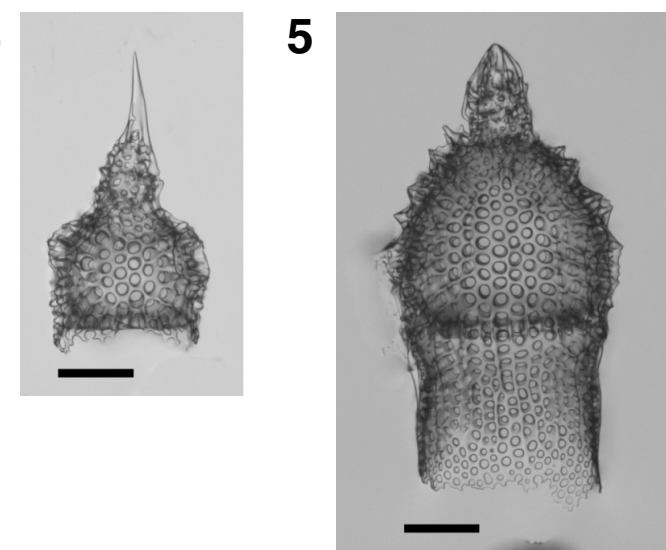

6

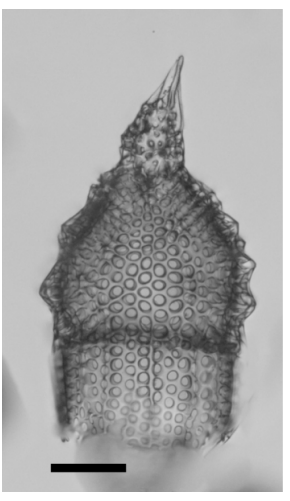

7

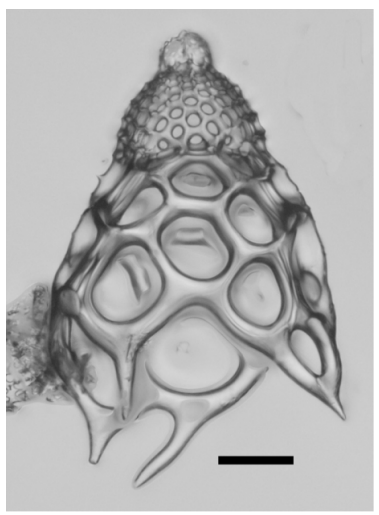

8

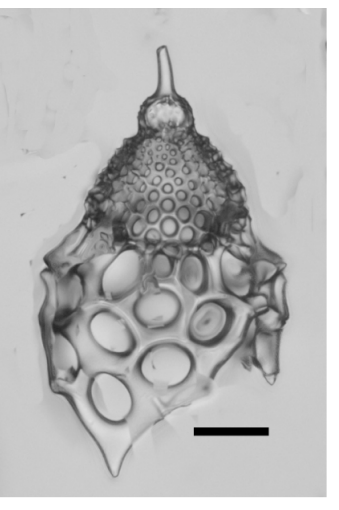

9

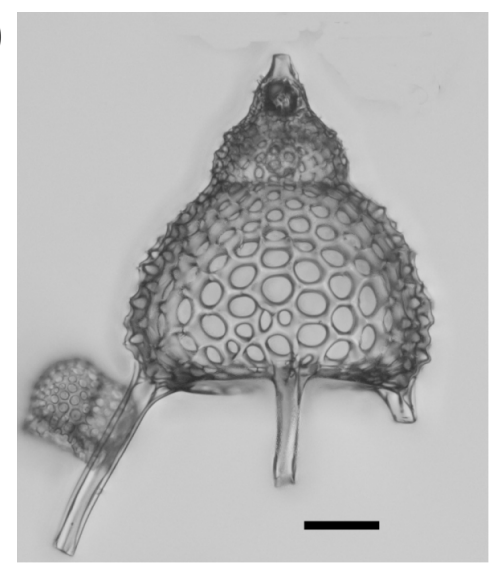

10

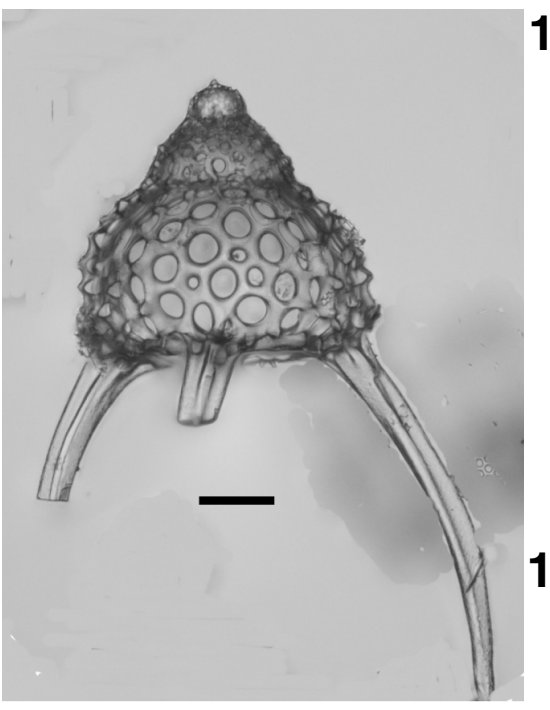

11

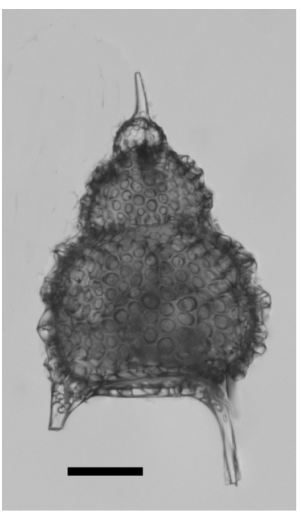

14

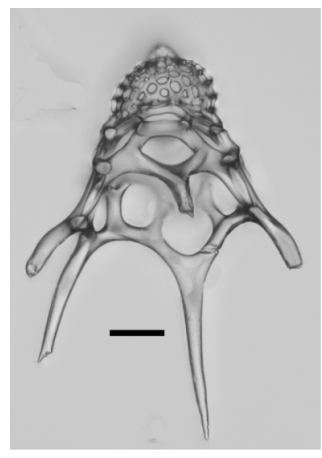

12

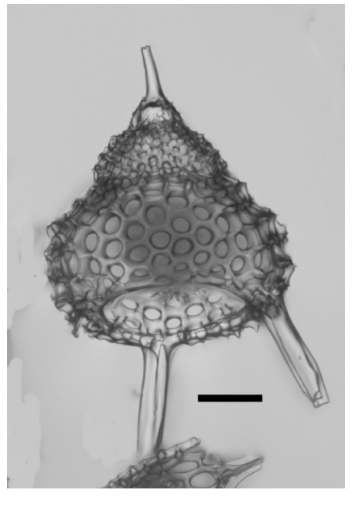

15

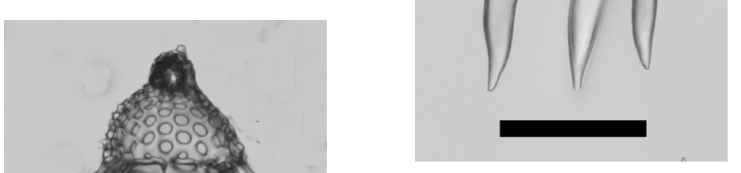

13

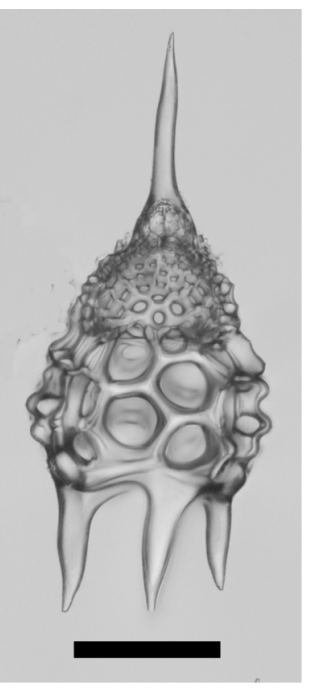


Plate P9. Thyrsocyrtis. All scale bars $=50 \mathrm{~mm}$. Sample depths are corrected and adjusted corresponding to depths (revised meters composite depth [rmcd]) in ODP Site 1218 (from Westerhold et al., 2012). (Plate shown on next page.)

1. Thyrsocyrtis (Pentalacorys) triacantha (Ehrenberg) (Sample 320-U1333A-14H-6, 140-141 cm; $259.03 \mathrm{rmcd}$ ).

2. Thyrsocyrtis (Pentalacorys) triacantha (Ehrenberg) (Sample 320-U1333A-11H-6, 140-141 cm; $259.03 \mathrm{rmcd}$ ).

3-10. Thyrsocyrtis (Thyrsocyrtis) bromia Ehrenberg group;(3) Sample 199-1218B-26X-3, 73-74 cm; 258.60 rmcd; (4) Sample 199-1218B-26X-3, 50-51 cm; 258.37 rmcd; (5) Sample 320-U1333A-14X-6, $40-41 \mathrm{~cm} ; 258.00 \mathrm{rmcd}$;

(6) Sample 320-U1333A-14X-4, 95-97 cm; 255.48 rmcd; (7) Sample 320-U1333A-14X-4, 95-97 cm; 255.48 rmcd; (8) Sample 199-1218B-25X-2, 137-138 cm; 253.68 rmcd; (9) Sample 320-U1333B-13X-7, 60-61cm; 249.54 rmcd; (10) Sample 320-U1333B-13X-7, 60-61 cm; 249.54 rmcd.

11. Thyrsocyrtis (Thyrsocyrtis) cf. T. (T.) norrisi Sanfilippo and Blome (Sample 320-U1333A-14H-7, 30-31 cm; $259.50 \mathrm{rmcd})$.

12. Thyrsocyrtis (Thyrsocyrtis) cf. T. (T.) norrisi Sanfilippo and Blome (Sample 320-U1333A-14H-7, 30-31 cm; $259.50 \mathrm{rmcd})$.

13-16. Thyrsocyrtis (Thyrsocyrtis) pinguisicoides O'Connor; (13) Sample 320-U1333A-14X-4, 140-141 cm; 259.03 rmcd; (14) Sample 320-U1333A-14X-4, 140-141 cm; 259.03 rmcd; (15) Sample 320-U1333A-14X-5, 110-111 cm; 257.12 rmcd; (16) Sample 320-U1333A-14X-5, 30-31 cm; 256.16 rmcd.

17-19. Thyrsocyrtis (Thyrsocyrtis) aff. T. (T.) pinguisicoides O'Conner; (17) Sample 320-U1333A-14X-7, 30-31 cm; 259.50 rmcd; 18) Sample 199-1218B-26X-3, 73-74 cm; 258.60 rmcd; (19) Sample 199-1218B-26X-3, 50-51 cm; $258.37 \mathrm{rmcd}$. 
Plate P9 (continued). (Caption shown on previous page.)
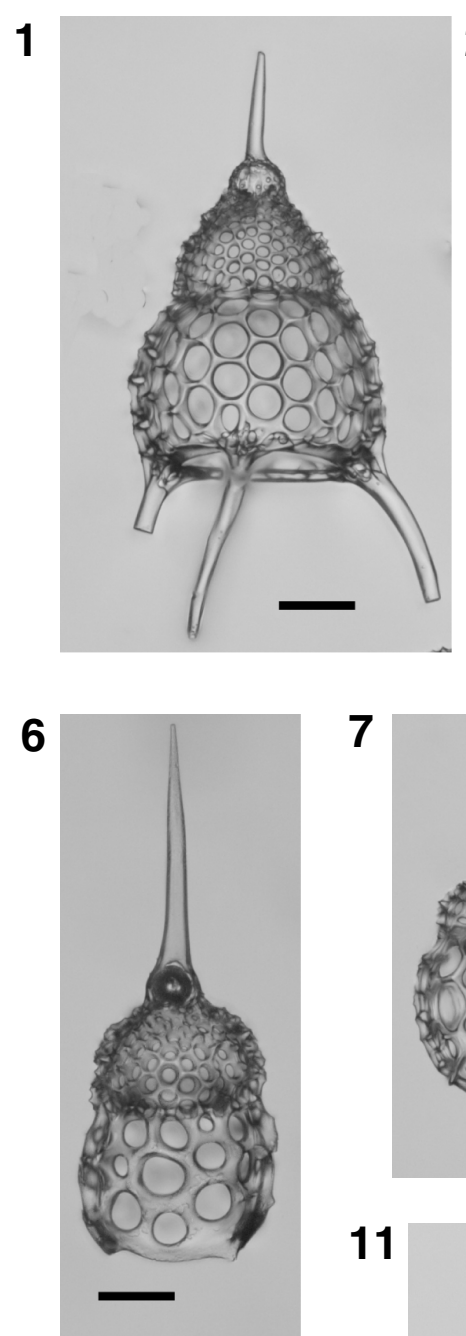

15

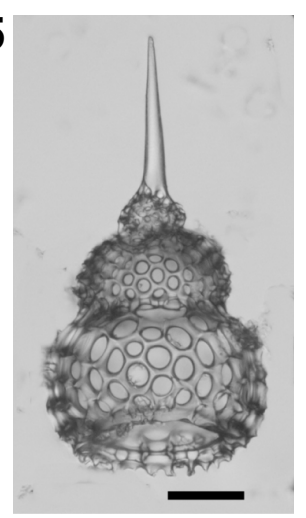

11

16
2
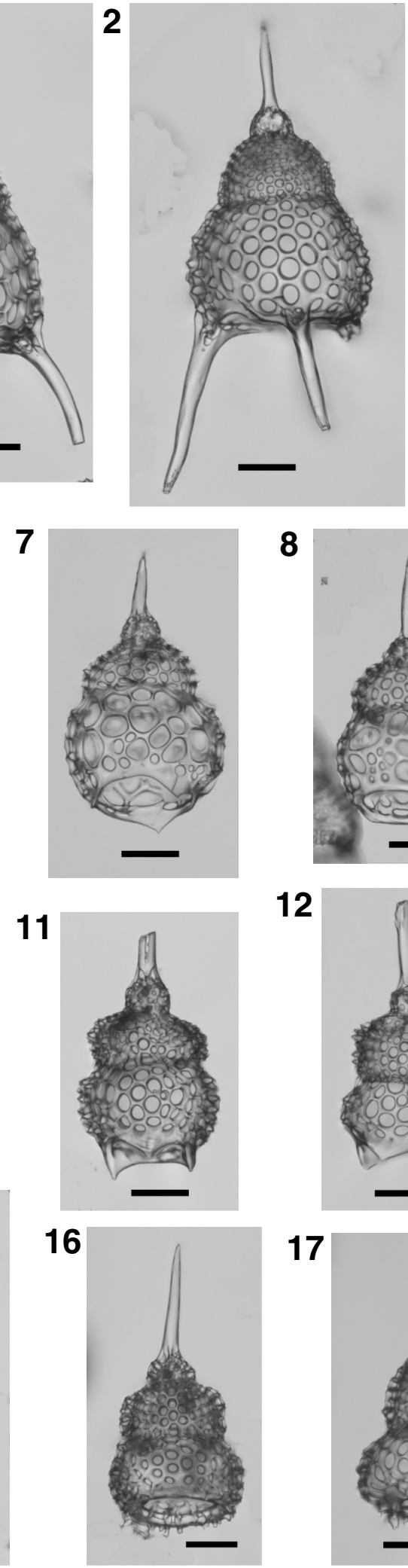

8

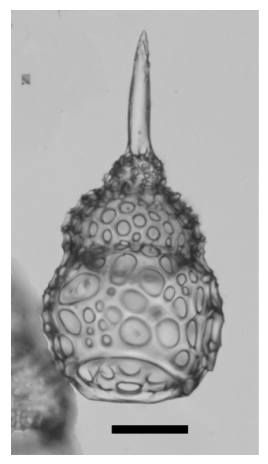

12

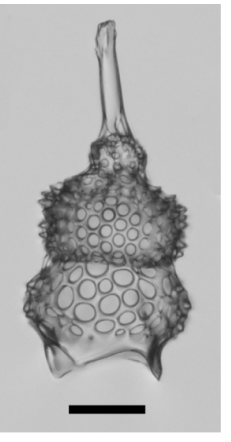

17

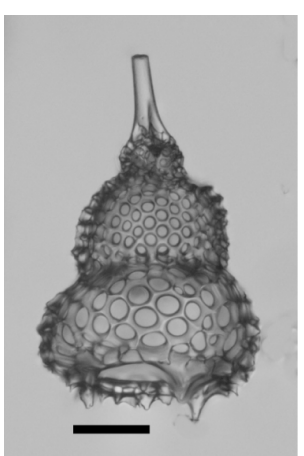

13
4
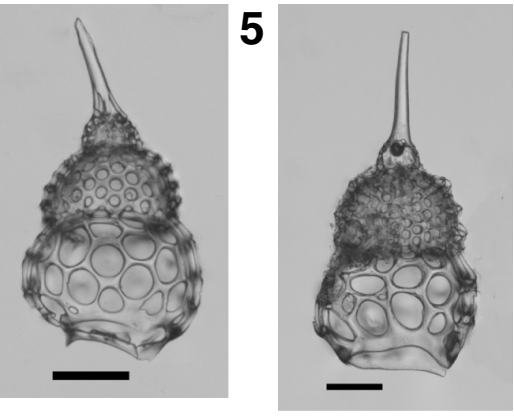

10
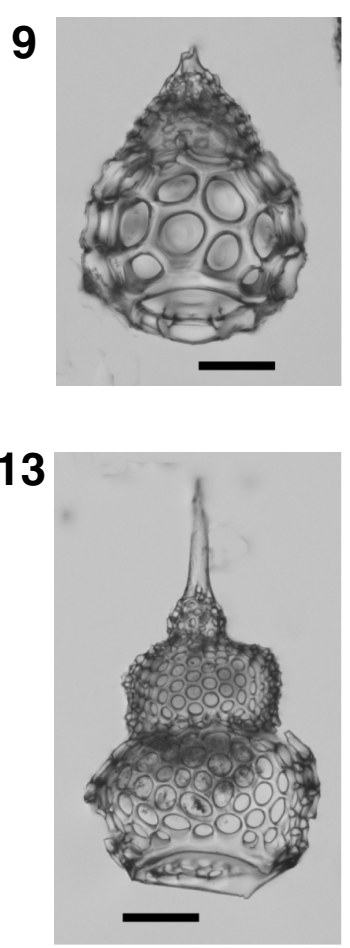

18

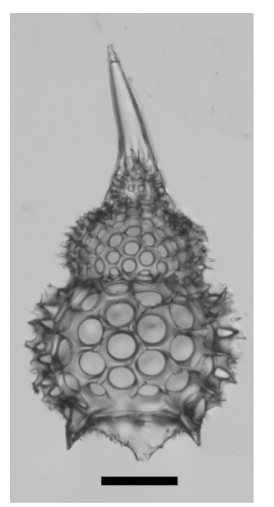

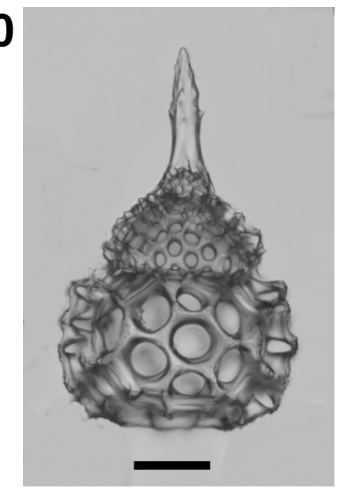

14

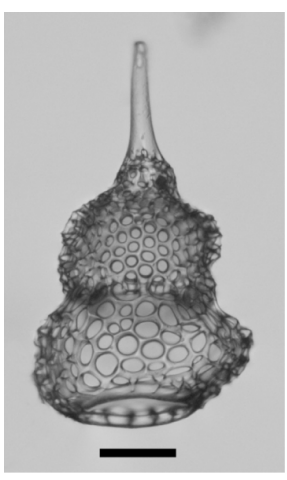

19

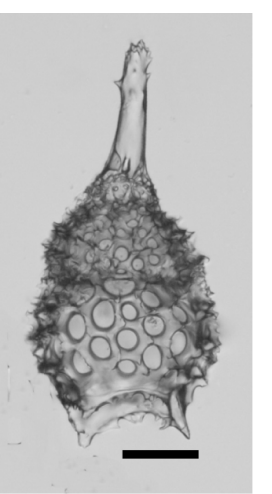


Plate P10. Thyrsocyrtis through Zygocircus. All scale bars $=50 \mathrm{~mm}$. Sample depths are corrected and adjusted corresponding to depths (revised meters composite depth [rmcd]) in ODP Site 1218 (from Westerhold et al., 2012). (Plate shown on next page.)

1. Thyrsocyrtis (Thyrsocyrtis) rhizodon Ehrenberg (Sample 320-U1333A-14H-7, $31 \mathrm{~cm} ; 259.50 \mathrm{rmcd}$ ).

2-4. Tristylospyris triceros (Ehrenberg);(2) Sample 320-U1334B-26X-5, 40-41 cm; 240.19 rmcd; (3) Sample 320-U1334A-26X-3, 50-51 cm; 231.57 rmcd; (4) Sample 320-U1334B-27X-4, 40-41 cm; 247.23 rmcd).

5. Zealithapium mitra (Ehrenberg) (Sample 320-U1333A-15X-3, 80-81 cm; $264.63 \mathrm{rmcd}$ ).

6. Zealithapium cf. Z. anoectum (Riedel and Sanfilippo) (Sample 320-U1333A-14H-4, 95-97 cm; 255.48 rmcd).

7. Zealithapium cf. Z. anoectum (Riedel and Sanfilippo) (Sample 320-U1333A-14X-4, 120-121 cm; $255.72 \mathrm{rmcd}$ ).

8. Zygocircus cimelium Petrushevskaya (Sample 320-U1333A-15X-4, 96-98 cm; $265.90 \mathrm{rmcd}$ ).

9. Zygocircus cimelium Petrushevskaya (Sample 320-U1333A-15X-3, 80-81 cm; $264.63 \mathrm{rmcd}$ ). 
Plate P10 (continued). (Caption shown on previous page.)

1

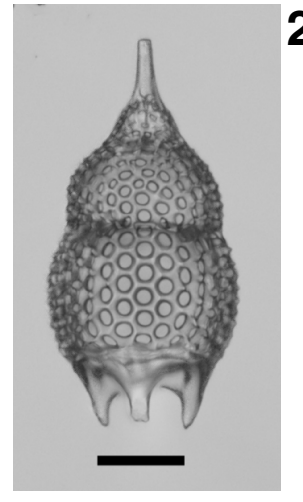

2

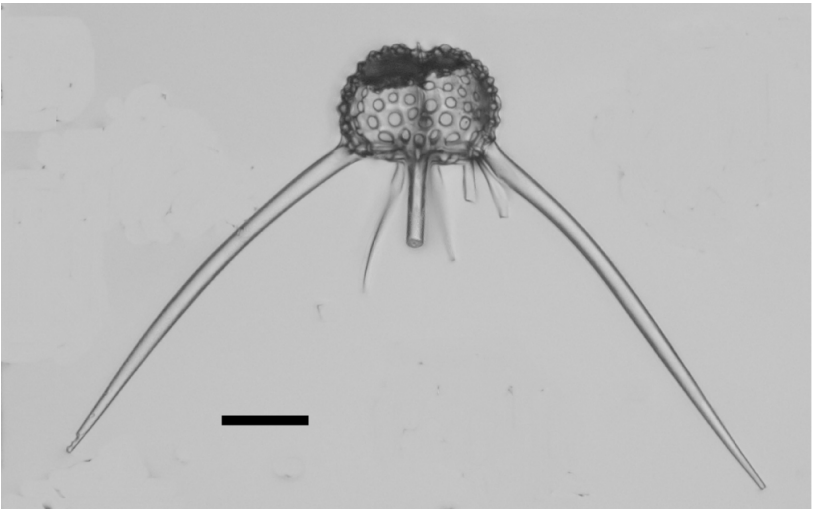

4

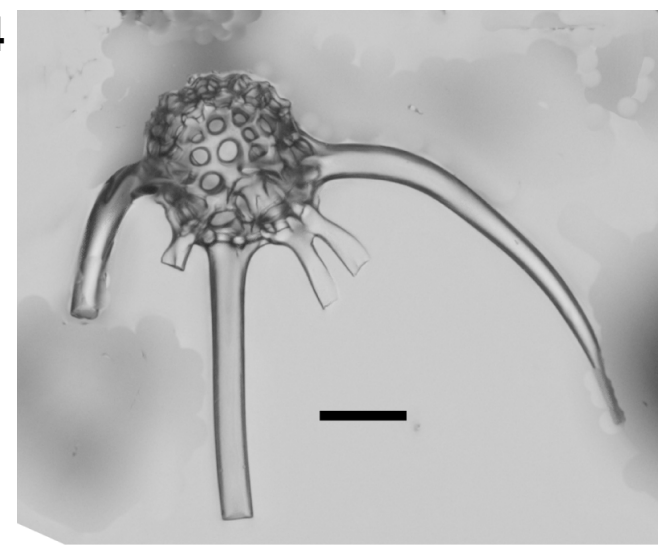

\section{3}

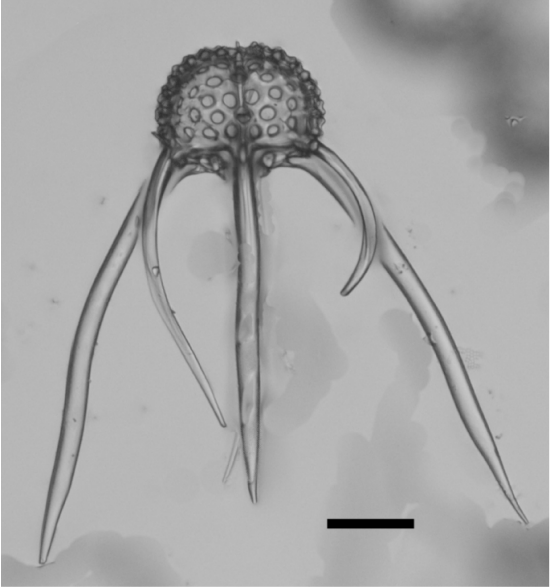

5

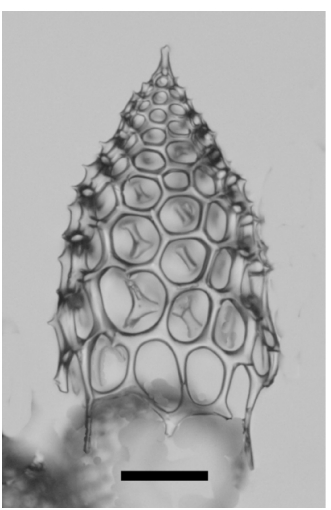

6

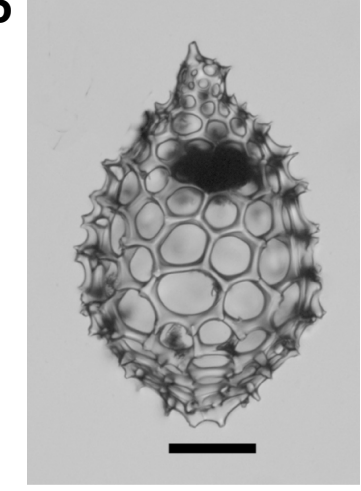

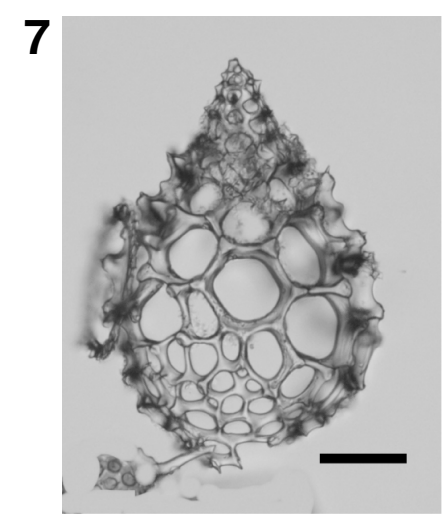

8

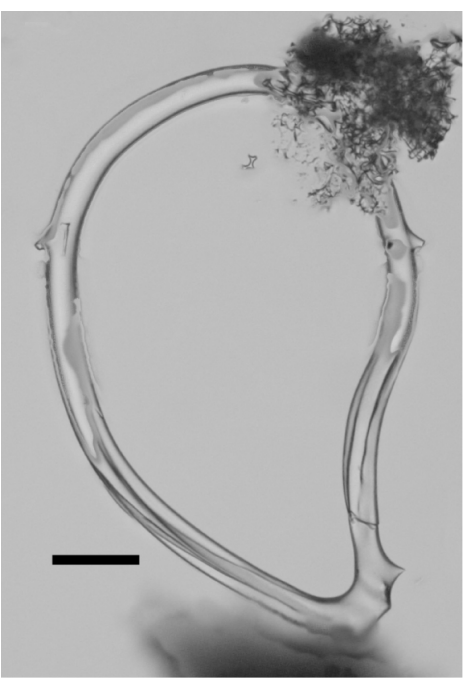

9

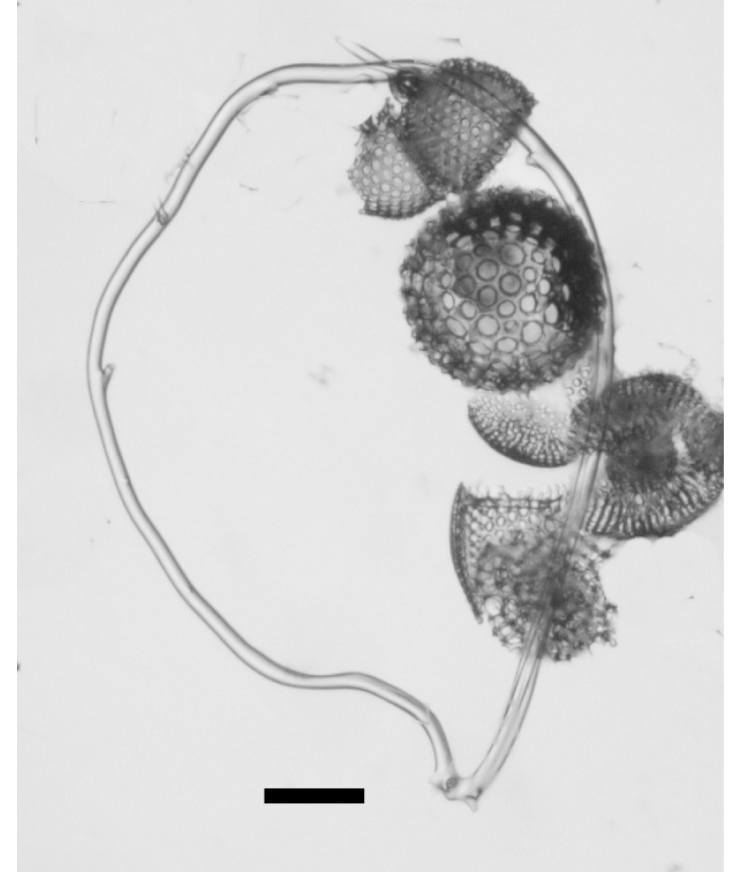

